\title{
Cloud condensation nuclei (CCN) from fresh and aged air pollution in the megacity region of Beijing
}

\author{
S. S. Gunthe ${ }^{1, *}$, D. Rose ${ }^{1}$, H. Su ${ }^{1}$, R. M. Garland ${ }^{1, * *}$, P. Achtert ${ }^{2}$, A. Nowak ${ }^{2}$, A. Wiedensohler ${ }^{2}$, M. Kuwata ${ }^{3, * * *}$, \\ N. Takegawa ${ }^{3}$, Y. Kondo ${ }^{3}$, M. Hü ${ }^{4}$, M. Shao ${ }^{4}$, T. Zhu ${ }^{4}$, M. O. Andreae ${ }^{1}$, and U. Pöschl ${ }^{1}$ \\ ${ }^{1}$ Biogeochemistry Department, Max Planck Institute for Chemistry, Mainz, Germany \\ ${ }^{2}$ Leibniz Institute for Tropospheric Research, Leipzig, Germany \\ ${ }^{3}$ RCAST, University of Tokyo, Tokyo, Japan \\ ${ }^{4}$ State Key Joint Laboratory of Environmental Simulation and Pollution Control, College of Environmental Sciences and \\ Engineering, Peking University, Beijing, China \\ *now at: EWRE Division, Department of Civil Engineering, Indian Institute of Technology Madras, Chennai, India \\ ** now at: Natural Resources and the Environment, Council for Scientific and Industrial Research, Pretoria, South Africa \\ ${ }^{* * *}$ now at: School of Engineering and Applied Sciences, Harvard University, Cambridge, Massachusetts, USA
}

Received: 2 February 2011 - Published in Atmos. Chem. Phys. Discuss.: 25 March 2011

Revised: 18 October 2011 - Accepted: 25 October 2011 - Published: 8 November 2011

\begin{abstract}
Atmospheric aerosol particles serving as cloud condensation nuclei $(\mathrm{CCN})$ are key elements of the hydrological cycle and climate. CCN properties were measured and characterized during the CAREBeijing-2006 campaign at a regional site south of the megacity of Beijing, China. Size-resolved CCN efficiency spectra recorded for a supersaturation range of $S=0.07 \%$ to $0.86 \%$ yielded average activation diameters in the range of $190 \mathrm{~nm}$ to $45 \mathrm{~nm}$. The corresponding effective hygroscopicity parameters $(\kappa)$ exhibited a strong size dependence ranging from $\sim 0.25$ in the Aitken size range to $\sim 0.45$ in the accumulation size range. The campaign average value $(\kappa=0.3 \pm 0.1)$ was similar to the values observed and modeled for other populated continental regions.

The hygroscopicity parameters derived from the $\mathrm{CCN}$ measurements were consistent with chemical composition data recorded by an aerosol mass spectrometer (AMS) and thermo-optical measurements of apparent elemental and organic carbon (EC and $\mathrm{OC}$ ). The $\mathrm{CCN}$ hygroscopicity and its size dependence could be parameterized as a function of only AMS based organic and inorganic mass fractions ( $f_{\text {org }}$, $\left.f_{\text {inorg }}\right)$ using the simple mixing rule $\kappa_{\mathrm{p}} \approx 0.1 \cdot f_{\text {org }}+0.7$. $f_{\text {inorg. }}$.
\end{abstract}

When the measured air masses originated from the north and passed rapidly over the center of Beijing (fresh city pollution), the average particle hygroscopicity was reduced ( $\kappa=$ $0.2 \pm 0.1)$, which is consistent with enhanced mass fractions of organic compounds $(\sim 50 \%)$ and $\mathrm{EC}(\sim 30 \%)$ in the fine particulate matter $\left(\mathrm{PM}_{1}\right)$. Moreover, substantial fractions of externally mixed weakly $\mathrm{CCN}$-active particles were observed at low supersaturation $(S=0.07 \%)$, which can be explained by the presence of freshly emitted soot particles with very low hygroscopicity $(\kappa<0.1)$. Particles in stagnant air from the industrialized region south of Beijing (aged regional pollution) were on average larger and more hygroscopic, which is consistent with enhanced mass fractions $(\sim 60 \%)$ of soluble inorganic ions (mostly sulfate, ammonium, and nitrate). Accordingly, the number concentration of $\mathrm{CCN}$ in aged air from the megacity region was higher than in fresh city outflow $\left((2.5-9.9) \times 10^{3} \mathrm{~cm}^{-3}\right.$ vs. $(0.4-8.3) \times 10^{3} \mathrm{~cm}^{-3}$ for $S=$ $0.07-0.86 \%$ ) although the total aerosol particle number concentration was lower $\left(1.2 \times 10^{4} \mathrm{~cm}^{-3}\right.$ vs. $\left.2.3 \times 10^{4} \mathrm{~cm}^{-3}\right)$. A comparison with related studies suggests that the fresh outflow from Chinese urban centers generally may contain more, but smaller and less hygroscopic aerosol particles and thus fewer $\mathrm{CCN}$ than the aged outflow from megacity regions. 


\section{Introduction}

Atmospheric aerosol particles that enable the condensation of water vapor and the formation of cloud droplets at a given level of water vapor supersaturation are called cloud condensation nuclei $(\mathrm{CCN})$. These aerosol particles play an important role in the formation of clouds and precipitation, and thus influence atmospheric chemistry and physics, and the hydrological cycle and climate (Seinfeld and Pandis, 2006; Lohmann and Feichter, 2005). Elevated concentrations of $\mathrm{CCN}$ tend to increase the concentration and reduce the size of the droplets in a cloud. Apart from changing the optical properties and the radiative effects of clouds on climate, this may lead to the suppression of precipitation in shallow and short lived clouds and to a greater convective overturning and more precipitation in deep convective clouds (Rosenfeld et al., 2008). The response of cloud characteristics and precipitation processes to increasing anthropogenic aerosol concentrations, however, represents one of the largest uncertainties in the current understanding of climate change (Andreae et al., 2005; IPCC, 2007). To incorporate the effects of CCN in meteorological models at scales from large eddy simulations (LES) to global climate models (GCMs), knowledge of the spatial and temporal distribution of $\mathrm{CCN}$ in the atmosphere is essential (Huang et al., 2007; Andreae and Rosenfeld, 2008; Stevens and Feingold, 2009; Pöschl et al., 2010).

In recent years, anthropogenic emissions of aerosol particles and precursors from Asia have increased significantly due to rapid industrialization (Streets et al., 2000, 2008; Richter et al., 2005; Shao et al., 2006), and numerous studies indicate that anthropogenic aerosol particles have changed cloud microphysical and radiative properties (Xu, 2001; Liu et al., 2004; Massie et al., 2004; Zhang et al., 2004; Wang et al., 2005; Qian et al., 2006; Zhao et al., 2006; Li et al., 2007; Rosenfeld et al., 2007; Matsui et al., 2010). Thus, CCN data are required for assessing the impact of anthropogenic aerosol on regional and global climate. Several earlier and recent studies have reported $\mathrm{CCN}$ measurements from various regions around the world, however, only few $\mathrm{CCN}$ measurements have been made in Asia and in the vicinity of megacities and city-clusters, which are major source regions of atmospheric particulate matter (e.g. Matsumoto et al., 1997; Yum et al., 2005, 2007; Kuwata et al., 2007, 2008, 2009; Wiedensohler et al., 2009; Rose et al., 2010, 2011).

Beijing, the capital of China, is a megacity with a population of about 20 million people (http://www.stats.gov.cn/ english/newsandcomingevents/t20110429_402722516.htm). The city is located in Northeastern China, it is surrounded by the Yanshan Mountains from the west to the northeast, and has heavily industrialized areas from the southwest to the east (Chen et al., 2007; Streets et al., 2007). Due to the rapid economic growth and the increase in motor traffic during the last decade, the pollution in Beijing is a complex mixture of local domestic, industrial, and traffic emissions and there is regional pollution originating from the highly industrialized areas to the south (i.e. Hebei province and Tianjin Municipality) (Xia et al., 2007; Wehner et al., 2008). Episodically there is also influence of dust or biomass burning, but this was not observed during our campaign. The "Campaign of Air Quality Research in Beijing and Surrounding Region 2006" (CAREBeijing-2006) took place in summer 2006. Its objectives were to study the origin of the regional air pollution and to advise the local authorities on measures to reduce local particulate pollution during the Olympic Games to be held in Beijing in August 2008. A suburban measurement location, Yufa, located $\sim 50 \mathrm{~km}$ south of the center of Beijing, enabled investigations of the southerly inflow into the city to probe the impact of aged regional pollution on the city's air quality, as well as investigations of the city outflow when winds were northerly (fresh city pollution).

In this study we report on the first size-resolved measurements of $\mathrm{CCN}$ in the megacity region of Beijing, and we parameterize the effective aerosol particle hygroscopicity and $\mathrm{CCN}$ activity as a function of chemical composition determined by aerosol mass spectrometry (AMS).

\section{Methods}

\subsection{Measurement location, aerosol inlets and supporting data}

The measurements were performed during the CAREBeijing-2006 campaign (10 August to 9 September 2006) at a suburban site on the campus of Huang $\mathrm{Pu}$ University in Yufa $\left(39.51467^{\circ} \mathrm{N}, 116.30533^{\circ} \mathrm{E}\right)$, which is located $\sim 50 \mathrm{~km}$ south of the city center of Beijing (Fig. 1). The instruments were located on the third and the top floor of a four story school building with the sample inlets and a meteorological station mounted on the roof (Achtert et al., 2009; Garland et al., 2009; Takegawa et al., 2009a,b; Wiedensohler et al., 2009). The average meteorological parameters (arithmetic mean \pm standard deviation) recorded during the campaign period at the aerosol inlet were: $24.6 \pm 4.4^{\circ} \mathrm{C}$ ambient temperature, $71.0 \pm 18.3 \%$ ambient relative humidity (RH), and $1005 \pm 4 \mathrm{hPa}$ ambient pressure. The winds were generally light $\left(1.70 \pm 1.38 \mathrm{~m} \mathrm{~s}^{-1}\right.$ average local wind speed) and came mostly from the south $\left(172 \pm 93^{\circ}\right.$ average local wind direction) with occasional shifts to northerly directions as detailed in the results section. Back trajectory analyses can be found in Garland et al. (2009).

The main aerosol inlet used in this study was equipped with a Rupprecht \& Patashnick $\mathrm{PM}_{10}$ inlet that was optimized for isokinetic flow conditions with a cyclone for the $10 \mu \mathrm{m}$ size cut-off (flow rate $16.71 \mathrm{~min}^{-1}$ ). The sample flow passed through stainless steel tubing $(1.9 \mathrm{~cm}$ inner diameter, $5.1 \mathrm{~m}$ length) to a diffusion dryer with silica 


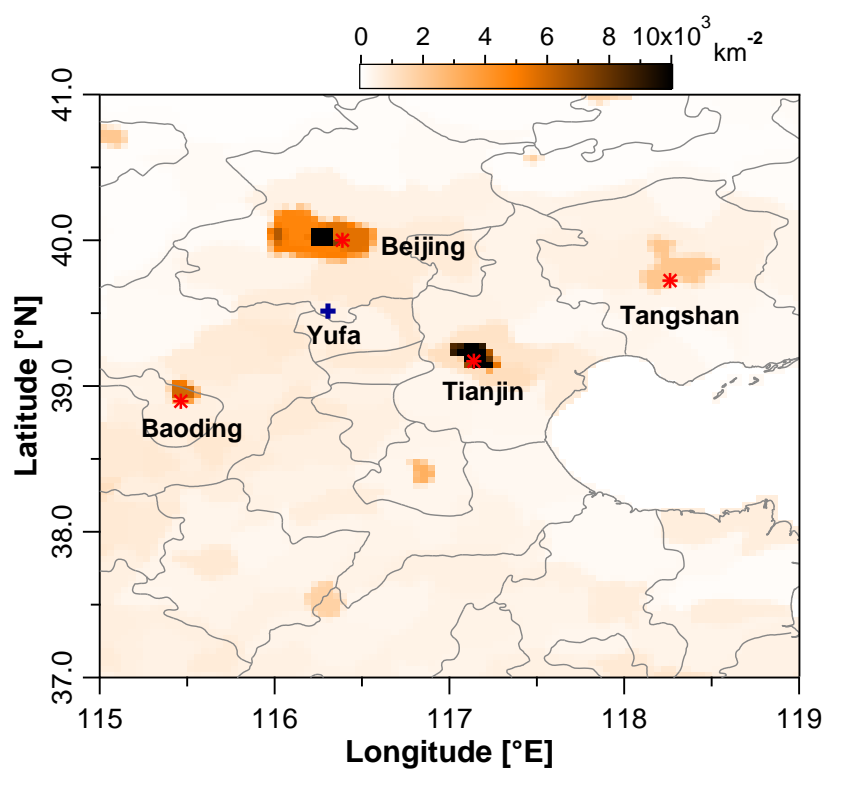

Fig. 1. Measurement location Yufa (blue cross) in the megacity region of Beijing, China. The map is color-coded by population density.

gel/molecular sieve cartridges (alternating regeneration with dry pressurized air, regeneration cycles 15-50 min, average $\mathrm{RH}=29 \pm 5 \%$; Tuch et al., 2009). After drying, the sample flow was split into separate lines. One line (stainless steel, $0.94 \mathrm{~cm}$ inner diameter, $\sim 7 \mathrm{~m}$ length, $1.51 \mathrm{~min}^{-1}$ flow rate) was for the $\mathrm{CCN}$ measurement setup described below, and another one was used for the aerosol size distribution measurements with a Twin Differential Mobility Particle Sizer (TDMPS, 3-900 nm particle diameter; Birmili et al., 1999; Achtert et al., 2009; Wiedensohler et al., 2009). The aerosol mass spectrometer (AMS) measurements presented in this paper were performed using a separate inlet and sampling line as described by Takegawa et al. (2009a,b).

The mass concentrations of apparent elemental carbon (EC) (Andreae and Gelencsér, 2006) and organic carbon (OC) were measured using a Sunset Laboratory semicontinuous EC/OC analyzer operated by the University of Tokyo and Peking University (Kondo et al., 2006). The time resolution was $1 \mathrm{~h}$, which included a sampling time of $40 \mathrm{~min}$ and an analysis time of $15 \mathrm{~min}$. The sample line for the EC/OC analyzer was a stainless steel tube with an inner diameter of $10 \mathrm{~mm}$ and a length of $\sim 9 \mathrm{~m}$. The ambient particles were collected on a quartz filter and then analyzed on the basis of the thermal-optical-transmittance method with a temperature protocol that was based on that proposed by the $\mathrm{Na}$ tional Institute for Occupational Safety and Health (NIOSH). More details regarding EC/OC measurement techniques and results during CAREBeijing-2006 are discussed elsewhere (Takegawa et al., 2009a). The campaign average values of EC/OC data reported in this study include only data points for which also CCN data were available.

\subsection{CCN measurements and data analysis}

Size-resolved CCN efficiency spectra (activation curves) were measured with a Droplet Measurement Technologies continuous flow CCN counter (DMT-CCNC, Roberts and Nenes, 2005; Lance et al., 2006) coupled to a Differential Mobility Analyzer (DMA; TSI 3071; sheath flow $101 \mathrm{~min}^{-1}$ ) and a condensation particle counter (CPC; TSI 3762; sample flow $1.01 \mathrm{~min}^{-1}$; Frank et al., 2006; Rose et al., 2008). The CCNC was operated at a total flow rate of $0.51 \mathrm{~min}^{-1}$ with a sheath-to-aerosol flow ratio of 10 .

The effective water vapor supersaturation $(S)$ was regulated by the temperature difference between the upper and lower end of the CCNC flow column $(\Delta T)$ and calibrated with ammonium sulfate aerosol as described by Rose et al. (2008, 2010, Köhler model AP3; calibration line $S=$ $k_{\mathrm{S}} \Delta T+S_{0}$ with $k_{\mathrm{S}}=0.0793 \% \mathrm{~K}^{-1}, S_{0}=-0.0909 \%, R^{2}=$ 0.9083 ; relative uncertainty $\Delta S / S<10 \%$ ). Note that high $\mathrm{CCN}$ number concentrations in the CCNC column can significantly depress the supersaturation generated in the column (Lathem and Nenes, 2011). For our measurements, however, we do not expect this effect since the highest $\mathrm{CCN}$ counts in the column were $\sim 400 \mathrm{~cm}^{-3}$.

For each $\mathrm{CCN}$ measurement cycle, $\Delta T$ was set to 5 different levels $(2.0-11.9 \mathrm{~K})$ corresponding to $S$ values in the range of $0.07-0.86 \%$. For each $\Delta T$ and the respective $S$, the diameter of the dry aerosol particles selected by the DMA (D) was set to 9 different values in the range of $20-290 \mathrm{~nm}$ depending on the supersaturation selected. At each $D$, the number concentration of total aerosol particles (condensation nuclei, $\mathrm{CN}$ ), $N_{\mathrm{CN}}$, was measured with the $\mathrm{CPC}$, and the number concentration of $\mathrm{CCN}, N_{\mathrm{CCN}}$, was measured with the CCNC. The integration time for each measurement data point was $30 \mathrm{~s}$, the recording of a $\mathrm{CCN}$ efficiency spectrum $\left(N_{\mathrm{CCN}} / N_{\mathrm{CN}}\right.$ vs. $\left.D\right)$ took $\sim 16 \mathrm{~min}$ (including a $50 \mathrm{~s}$ adjustment time for each new particle size and 4 min for adjustment to the next supersaturation level), and the completion of a full measurement cycle comprising $\mathrm{CCN}$ efficiency spectra at 5 different supersaturation levels took $\sim 85$ min (including $5 \mathrm{~min}$ of settling time for the changeover from highest to lowest $S$ ).

Approximately 300 measurement cycles, corresponding to $\sim 1500 \mathrm{CCN}$ efficiency spectra, were performed during the CAREBeijing-2006 campaign, with occasional short term interruptions and one long term interruption (24 August to 1 September) for instrument calibration and maintenance. The measurement data of the $\mathrm{CCN}$ efficiency spectra were corrected for the effects of multiply charged particles, differences in the CCNC and CPC counting efficiencies with a correction factor $f_{\text {corr }}\left(f_{\text {corr }}=x_{1}-x_{2} \cdot x_{3}^{D} ; x_{1}=0.9108\right.$, $x_{2}=0.2489$, and $x_{3}=0.9746$, with $D$ being the diameter in $\mathrm{nm}$ and $\left.R^{2}=0.95\right)$, and the DMA transfer function as described in detail by Rose et al. (2010). For the multiple charge correction (Frank et al., 2006), we used the total aerosol particle number size distributions that were measured 
Table 1. List and short description of symbols and parameters frequently used in this study. Details about definitions and derivations are described in the text.

\begin{tabular}{|c|c|c|}
\hline Symbol & Unit & Description \\
\hline$D$ & $\mathrm{~nm}$ & mobility equivalent particle diameter \\
\hline$D_{\mathrm{a}}$ & $\mathrm{nm}$ & midpoint activation diameter determined by a 3-parameter CDF fit \\
\hline$D_{\mathrm{t}}$ & $\mathrm{nm}$ & $\begin{array}{l}\text { midpoint activation diameter determined by a 2-parameter CDF fit } \\
\text { in which the maximum is limited to unity; representing the total } \\
\text { ensemble of aerosol }\end{array}$ \\
\hline$f_{\text {inorg }}$ & & inorganic mass fraction detected by the AMS \\
\hline$f_{\text {org }}$ & & organic mass fraction detected by the AMS \\
\hline $\mathrm{MAF}_{\mathrm{f}}$ & & maximum activated fraction determined by a 3-parameter CDF fit \\
\hline $\mathrm{MAF}_{\mathrm{m}}$ & & activated fraction measured at the largest selected diameter $(\sim 270 \mathrm{~nm})$ \\
\hline$N_{\mathrm{CCN}, \mathrm{S}}$ & $\mathrm{cm}^{-3}$ & calculated number concentration of $\mathrm{CCN}$ at a given supersaturation \\
\hline$N_{\mathrm{CN}, \text { tot }}$ & $\mathrm{cm}^{-3}$ & total number concentration of aerosol particles $(3-800 \mathrm{~nm})$ \\
\hline$N_{\mathrm{CN}, 30}$ & $\mathrm{~cm}^{-3}$ & total number concentration of aerosol particles with $D>30 \mathrm{~nm}$ \\
\hline$S$ & $\%$ & water vapor supersaturation \\
\hline$\kappa_{\mathrm{a}}$ & & $\begin{array}{l}\text { effective hygroscopicity parameter characteristic for } \mathrm{CCN} \text {-active } \\
\text { particles; calculated from fit parameter } D_{\mathrm{a}}\end{array}$ \\
\hline$\kappa_{\mathrm{t}}$ & & $\begin{array}{l}\text { hygroscopicity parameter characteristic for the total ensemble of aerosol } \\
\text { particles, including internally mixed } \mathrm{CCN} \text {-active particles as well as } \\
\text { externally mixed weakly CCN-active particles; derived from the fit } \\
\text { parameter } D_{\mathrm{t}}\end{array}$ \\
\hline$\kappa_{\text {inorg }}$ & & effective hygroscopicity of aerosol particles constituting inorganic mass \\
\hline$\kappa_{\text {org }}$ & & effective hygroscopicity of aerosol particles constituting organic mass \\
\hline$\kappa_{\mathrm{p}}$ & & predicted effective hygroscopicity parameter as calculated from Eq. (1) \\
\hline$\sigma_{\mathrm{a}}$ & $\mathrm{nm}$ & $\begin{array}{l}\text { standard deviation of a 3-parameter CDF fit; characterizes the hetero- } \\
\text { geneity of CCN-active particles in the size range around } D_{\mathrm{a}}\end{array}$ \\
\hline
\end{tabular}

in parallel with CCN measurements by the TDMPS. For several CCN measurement cycles, TDMPS data were not available, and hence no charge correction was applied. However, the $\mathrm{CCN}$ data from these cycles remained comparable with the corrected ones, because the effect of the charge correction was generally small $(<5 \%$ change in the activation diameters and other parameters used for further analysis; Rose et al., 2008, 2010). The uncertainties of $N_{\mathrm{CCN}}, N_{\mathrm{CN}}$ and $N_{\mathrm{CCN}} / N_{\mathrm{CN}}$ were estimated to be $<20 \%$ for individual measurement data points and $<10 \%$ for average values and fit parameters (Rose et al., 2008, 2010).

By fitting with a cumulative Gaussian distribution function (CDF), the following parameters were derived from each measured CCN efficiency spectrum (Gunthe et al., 2009; Rose et al., 2010): the maximum activated fraction $\mathrm{MAF}_{\mathrm{f}}$, the midpoint activation diameter $D_{\mathrm{a}}$, and the standard deviation $\sigma_{\mathrm{a}}$ of 3-parameter CDF fits, as well as the midpoint activation diameter $D_{\mathrm{t}}$ and the standard deviation $\sigma_{\mathrm{t}}$ of 2parameter CDF fits with $\mathrm{MAF}_{\mathrm{f}}$ set to 1 . Note that the CCN efficiency measured at the largest diameter of each spectrum $\left(\mathrm{MAF}_{\mathrm{m}}=N_{\mathrm{CCN}} / N_{\mathrm{CN}}\right.$ at $D_{\max }$ ) was generally in good agreement with $\mathrm{MAF}_{\mathrm{f}}$ as derived from the 3-parameter CDF fit (deviations $<10 \%$ ). Key parameters derived from the measured CCN spectra and other related parameters used in the present study are listed and briefly explained in Table 1.
As detailed by Rose et al. (2010) the activation diameters and standard deviations derived from the 3-parameter and 2parameter $\mathrm{CDF}$ fits are not the same for $\mathrm{CCN}$ efficiency spectra with $\mathrm{MAF}_{\mathrm{f}}<1$ : the 3-parameter fit results represent the average properties of the $\mathrm{CCN}$-active aerosol particle fraction, whereas the 2-parameter fit results are proxies for the effective overall properties of the external mixture of $\mathrm{CCN}$ active and $\mathrm{CCN}$-inactive particles. In the remainder of this study we will focus on the 3-parameter fit results.

The difference between unity and the maximum observed $\mathrm{CCN}$ efficiency $\left(1-\mathrm{MAF}_{\mathrm{m}}\right.$ or $\left.1-\mathrm{MAF}_{\mathrm{f}}\right)$ represents the fraction of externally mixed $\mathrm{CCN}$-inactive particles measured at $D_{\text {max }}$ or fitted over the whole diameter range of each scan, respectively. Though derived from a fit to the whole scan, $\mathrm{MAF}_{\mathrm{f}}$ is only valid at $D_{\max }$ and the nearby diameter range with a plateau of activated particle fraction $N_{\mathrm{CCN}} / N_{\mathrm{CN}}$. Particles that are $\mathrm{CCN}$-inactive at $D_{\max }$ can be regarded as weakly $\mathrm{CCN}$-active particles with hygroscopicity parameters below the threshold value $\kappa_{\mathrm{c}}=\kappa\left(D_{\max }, S\right)$ (Su et al., 2010).

The CDF standard deviations are general indicators for the mixing state and heterogeneity of particle composition in the investigated aerosol: $\sigma_{\mathrm{a}}$ characterizes the $\mathrm{CCN}$-active particles in the size range around $D_{\mathrm{a}}$, and $\sigma_{\mathrm{t}}$ is a measure for the overall heterogeneity of $\mathrm{CCN}$-active and -inactive particles in the size range around $D_{\mathrm{t}}$. Under ideal conditions, the CDF standard deviations should be zero for an internally mixed, 
fully monodisperse aerosol with particles of homogeneous chemical composition. Even after correcting for the DMA transfer function, however, calibration aerosols composed of high purity ammonium sulfate exhibit small non-zero $\sigma_{\mathrm{a}}$ values that correspond to $\sim 3 \%$ of $D_{\mathrm{a}}$ and can be attributed to heterogeneities of the water vapor supersaturation profile in the CCNC or other non-idealities, such as DMA transfer function or particle shape effects. Thus, increasing values of the normalized CDF standard deviation or "heterogeneity parameter" indicate increasing heterogeneity of particle composition (Rose et al., 2010; Gunthe et al., 2009; Su et al., 2010).

For all data pairs of supersaturation and activation diameter derived from the $\mathrm{CCN}$ efficiency spectra measured in this study, effective hygroscopicity parameters $\kappa$ were calculated using the $\kappa$-Köhler model equations and parameters specified in Rose et al. (2010) (surface tension $0.072 \mathrm{~J} \mathrm{~m}^{-2}$, temperature $298 \mathrm{~K}$ ). Note that the $\kappa$ values derived from CCN measurement data through Köhler model calculations assuming the surface tension of pure water have to be regarded as "effective hygroscopicity parameters" that account not only for the reduction of water activity by the solute ("effective Raoult parameters") but also for surface tension effects (Petters and Kreidenweis, 2007; Mikhailov et al., 2009; Pöschl et al., 2009; Gunthe et al., 2009; Rose et al., 2010).

The parameter $\kappa_{\mathrm{a}}$ calculated from the data pairs of $S$ and $D_{\mathrm{a}}$ characterizes the average hygroscopicity of $\mathrm{CCN}$-active particles in the size range around $D_{\mathrm{a}} . \kappa_{\mathrm{t}}$ calculated from $D_{\mathrm{t}}$ is an approximate measure (proxy) for the effective hygroscopicity of mixtures of $\mathrm{CCN}$-active and -inactive particles in the size range around $D_{\mathrm{t}}$ (Rose et al., 2010). As discussed in earlier studies (Gunthe et al., 2009; Rose et al., 2010, 2011), $\kappa_{\mathrm{a}}$ is better suited for comparison with $\kappa$ values predicted from AMS measurements, because $\kappa_{\mathrm{a}}$ is not influenced by weakly $\mathrm{CCN}$-active particles consisting mostly of insoluble and refractory materials like mineral dust and soot (or biopolymers that tend to char upon heating), which are also not (or less efficiently) detected by AMS. On the other hand, $\kappa_{\mathrm{t}}$ is better suited for the single parameter prediction of $\mathrm{CCN}$ number concentrations when $\mathrm{CCN}$-active particles are externally mixed with CCN-inactive particles (Gunthe et al., 2009; Rose et al., 2010, 2011).

The statistical uncertainty in the determination of activation diameters by curve fitting (standard error of the CDF fit parameters) was on average $\sim 2-3 \mathrm{~nm}(\sim 1-5 \%)$. According to the relative sensitivities specified by Kreidenweis et al. (2009), the uncertainty of $1-5 \%$ in diameter corresponds to an uncertainty of 3-15\% in $\kappa$, and the uncertainty of $<10 \%$ in supersaturation reported above corresponds to an uncertainty of $<20 \%$ in $\kappa$ (Su et al., 2010). The reported campaign average values of $\mathrm{CCN}$ parameters include all available data points unless mentioned otherwise.

\subsection{AMS measurements and data analysis}

An Aerodyne quadrupole aerosol mass spectrometer (QAMS, hereafter referred to as "AMS" for brevity) was used to measure the size-resolved chemical composition of nonrefractory (vaporized at $\sim 600^{\circ} \mathrm{C}$ under vacuum) submicron aerosol particles (Jayne et al., 2000). Sampling information, data analysis technique, and performance of the AMS during the CAREBeijing-2006 campaign is described in detail by Takegawa et al. (2009a). The AMS data used in this study comprise a time series of mass size distributions $\left(\mathrm{d} M / \mathrm{d} \log D_{\text {va }}, \sim 10\right.$ min time resolution) where $D_{\text {va }}$ is the vacuum aerodynamic diameter (DeCarlo et al., 2004). The mass size distributions were calculated for inorganic ions $\left(\mathrm{SO}_{4}^{2-}, \mathrm{NH}_{4}^{+}, \mathrm{NO}_{3}^{-}, \mathrm{Cl}^{-}\right)$and organic matter $(\mathrm{Org})$ in the size range between $45 \mathrm{~nm}$ and $1.4 \mu \mathrm{m}$.

The mass concentration data of every size bin were averaged with the two adjacent size bins to minimize the influence of noise. To make the size-resolved AMS results directly comparable with the $\mathrm{CCN}$ measurement results, all calculations and plots in this study using AMS data were based on approximate mobility equivalent diameters that have been calculated by division of the AMS vacuum aerodynamic diameter through a density scaling factor of 1.6. The scaling factor is based on the assumption of an effective particle density of $1.6 \mathrm{~g} \mathrm{~cm}^{-3}$ (Achtert et al., 2009; van Pinxteren et al., 2009). Accordingly, the scaled AMS mass size distributions span a mobility size range of $29 \mathrm{~nm}$ to $900 \mathrm{~nm}$.

Size-resolved mass fractions were calculated diameterwise from the size distributions of mass concentration. The mass fraction of one chemical component is its mass concentration divided by the sum of the masses of all components at this diameter. To describe the chemical composition of the particles activated at the midpoint of the CCN efficiency spectrum, the AMS mass concentrations were integrated over the size interval of $D_{\mathrm{a}}-\sigma_{\mathrm{a}}$ to $D_{\mathrm{a}}+\sigma_{\mathrm{a}}$ (activation diameter \pm CDF standard deviation). The mass concentrations within these intervals $\left(m_{\mathrm{D}}\right)$ were used to calculate mass fractions of inorganic and organic compounds $\left(f_{\text {inorg }}, f_{\text {org }}\right)$ for correlation analysis. For this purpose, the AMS data set was adjusted to the time resolution of the $\mathrm{CCN}$ data. The AMS data point corresponding to a CCN data point was chosen to be the one that is closest in time within a time interval of $\pm 10 \mathrm{~min}$. If, for a CCN data point no corresponding AMS data point was available, the CCN data point was excluded from the analysis. The campaign average values of AMS data reported in this study include only data points for which also CCN data were available (see time series plots). 
Table 2. Characteristic CCN parameters (arithmetic mean values \pm standard deviations) listed for the entire campaign, for the focus periods of aged regional pollution and of fresh city pollution, and for the data from the PRIDE-PRD2006 campaign (entire campaign excluding biomass burning event, Rose et al., 2010): midpoint activation diameters $\left(D_{\mathrm{a}}, D_{\mathrm{t}}\right)$, maximum activated fractions $\left(\mathrm{MAF}_{\mathrm{f}}, \mathrm{MAF}_{\mathrm{m}}\right), \mathrm{CDF}$ standard deviations $\left(\sigma_{\mathrm{a}}, \sigma_{\mathrm{t}}\right)$, heterogeneity parameters $\left(\sigma_{\mathrm{a}} / D_{\mathrm{a}}, \sigma_{\mathrm{t}} / D_{\mathrm{t}}\right)$, hygroscopicity parameters $\left(\kappa_{\mathrm{a}}, \kappa_{\mathrm{t}}\right)$, number concentrations of total aerosol particles $\left(N_{\mathrm{CN}, \text { tot }}\right)$ and with $D>30 \mathrm{~nm}\left(N_{\mathrm{CN}, 30}\right)$, number concentrations of cloud condensation nuclei $\left(N_{\mathrm{CCN}, \mathrm{S}}\right)$, integral CCN efficiencies $\left(N_{\mathrm{CCN}, \mathrm{S}} / N_{\mathrm{CN} \text {,tot }}, N_{\mathrm{CCN}, \mathrm{S}} / N_{\mathrm{CN}, 30}\right) \cdot n_{\mathrm{ES}}$ and $n_{\mathrm{SD}}$ are the numbers of averaged CCN efficiency spectra and size distributions, respectively. Subscripts a and t stand for parameters derived from 3-parameter and 2-parameter CDF fits to the measured CCN efficiency spectra, respectively. For corresponding median values see Table S1.

\begin{tabular}{|c|c|c|c|c|c|c|c|c|c|c|c|c|c|c|c|c|c|}
\hline$S(\%)$ & $D_{\mathrm{a}}(\mathrm{nm})$ & $D_{\mathrm{t}}(\mathrm{nm})$ & $\mathrm{MAF}_{\mathrm{f}}$ & $\mathrm{MAF}_{\mathrm{m}}$ & $\sigma_{\mathrm{a}}(\mathrm{nm})$ & $\sigma_{\mathrm{t}}(\mathrm{nm})$ & $\sigma_{\mathrm{a} /} / D_{\mathrm{a}}$ & $\sigma_{\mathrm{t}} / D_{\mathrm{t}}$ & $\kappa_{\mathrm{a}}$ & $\kappa_{\mathrm{t}}$ & $\begin{array}{c}N_{\mathrm{CN}, \text { tot }} \\
\left(10^{3} \mathrm{~cm}^{-3}\right) \\
\end{array}$ & $\begin{array}{c}N_{\mathrm{CN}, 30} \\
\left(10^{3} \mathrm{~cm}^{-3}\right) \\
\end{array}$ & $\begin{array}{c}N_{\mathrm{CCN}, \mathrm{S}} \\
\left(10^{3} \mathrm{~cm}^{-3}\right) \\
\end{array}$ & $\begin{array}{c}N_{\mathrm{CCN}, \mathrm{S}} / \\
N_{\mathrm{CN}, \mathrm{tot}}\end{array}$ & $\begin{array}{c}N_{\mathrm{CCN}, \mathrm{S}} / \\
N_{\mathrm{CN}, 30} \\
\end{array}$ & $n_{\mathrm{ES}}$ & $n_{\mathrm{SD}}$ \\
\hline \multicolumn{18}{|c|}{ Entire campaign } \\
\hline 0.07 & $191.1 \pm 10.1$ & $203.9 \pm 25.0$ & $0.81 \pm 0.13$ & $0.81 \pm 0.13$ & $12.2 \pm 6.6$ & $32.6 \pm 24.4$ & $0.036 \pm 0.034$ & $0.151 \pm 0.096$ & $0.46 \pm 0.07$ & $0.40 \pm 0.11$ & $16.10 \pm 8.96$ & $11.62 \pm 4.00$ & $1.70 \pm 1.10$ & $0.13 \pm 0.10$ & $0.16 \pm 0.10$ & 269 & 269 \\
\hline 0.26 & $85.3 \pm 8.3$ & $88.8 \pm 12.0$ & $0.90 \pm 0.10$ & $0.91 \pm 0.10$ & $8.5 \pm 6.8$ & $12.8 \pm 10.7$ & $0.095 \pm 0.066$ & $0.134 \pm 0.092$ & $0.34 \pm 0.09$ & $0.31 \pm 0.10$ & $16.53 \pm 8.92$ & $11.67 \pm 4.10$ & $5.66 \pm 2.68$ & $0.41 \pm 0.21$ & $0.49 \pm 0.19$ & 285 & 285 \\
\hline 0.46 & $63.2 \pm 8.0$ & $64.4 \pm 9.2$ & $0.95 \pm 0.07$ & $0.95 \pm 0.07$ & $5.9 \pm 5.1$ & $7.0 \pm 6.3$ & $0.087 \pm 0.063$ & $0.100 \pm 0.074$ & $0.28 \pm 0.08$ & $0.27 \pm 0.01$ & $16.80 \pm 9.10$ & $11.72 \pm 4.16$ & $7.66 \pm 3.46$ & $0.54 \pm 0.23$ & $0.65 \pm 0.19$ & 271 & 271 \\
\hline 0.66 & $52.6 \pm 6.9$ & $53.7 \pm 7.9$ & $0.95 \pm 0.06$ & $0.95 \pm 0.06$ & $6.0 \pm 4.5$ & $7.1 \pm 5.7$ & $0.107 \pm 0.068$ & $0.124 \pm 0.080$ & $0.24 \pm 0.08$ & $0.23 \pm 0.08$ & $16.67 \pm 9.01$ & $11.66 \pm 4.17$ & $8.67 \pm 3.68$ & $0.60 \pm 0.23$ & $0.74 \pm 0.16$ & 278 & 278 \\
\hline 0.86 & $44.3 \pm 5.4$ & $44.8 \pm 5.9$ & $0.96 \pm 0.06$ & $0.98 \pm 0.06$ & $4.6 \pm 2.9$ & $5.1 \pm 3.4$ & $0.100 \pm 0.055$ & $0.109 \pm 0.059$ & $0.23 \pm 0.08$ & $0.22 \pm 0.08$ & $16.42 \pm 8.94$ & $11.47 \pm 3.85$ & $9.49 \pm 3.72$ & $0.66 \pm 0.23$ & $0.82 \pm 0.14$ & 269 & 269 \\
\hline All & & & & & & & $0.090 \pm 0.055$ & $0.121 \pm 0.077$ & $0.31 \pm 0.08$ & $0.28 \pm 0.09$ & $16.51 \pm 9.00$ & $11.63 \pm 4.10$ & & & & 1372 & 1372 \\
\hline \multicolumn{18}{|c|}{ Aged regional pollution } \\
\hline 0.07 & $185.2 \pm 5.1$ & $186.6 \pm 5.0$ & $0.91 \pm 0.05$ & $0.94 \pm 0.07$ & $7.8 \pm 6.1$ & $11.6 \pm 8.6$ & $0.043 \pm 0.035$ & $0.063 \pm 0.048$ & $0.50 \pm 0.05$ & $0.49 \pm 0.04$ & $11.72 \pm 2.61$ & $10.70 \pm 2.17$ & $2.46 \pm 0.65$ & $0.22 \pm 0.06$ & $0.24 \pm 0.07$ & 34 & 34 \\
\hline 0.26 & $81.3 \pm 4.4$ & $82.5 \pm 5.3$ & $0.94 \pm 0.05$ & $0.99 \pm 0.09$ & $6.7 \pm 3.2$ & $8.5 \pm 4.7$ & $0.081 \pm 0.037$ & $0.101 \pm 0.052$ & $0.38 \pm 0.06$ & $0.36 \pm 0.07$ & $12.17 \pm 3.19$ & $11.06 \pm 2.57$ & $7.29 \pm 0.87$ & $0.62 \pm 0.08$ & $0.68 \pm 0.09$ & 33 & 33 \\
\hline 0.46 & $59.3 \pm 3.0$ & $59.9 \pm 4.2$ & $0.96 \pm 0.05$ & $0.98 \pm 0.06$ & $4.1 \pm 2.2$ & $4.8 \pm 3.5$ & $0.069 \pm 0.037$ & $0.078 \pm 0.050$ & $0.31 \pm 0.05$ & $0.31 \pm 0.06$ & $12.11=$ & 10.91 & & 0.08 & $0.82=$ & 34 & 34 \\
\hline 0.66 & $50.1 \pm 4.0$ & $50.7 \pm 4.0$ & $0.97 \pm 0.05$ & $0.97 \pm 0.06$ & $4.8 \pm 2.2$ & $5.5 \pm 2.5$ & $0.094 \pm 0.038$ & $0.106 \pm 0.044$ & $0.26 \pm 0.06$ & $0.25 \pm 0.06$ & $11.64 \pm 2.74$ & $10.72 \pm 2.37$ & $9.19 \pm 1.74$ & $0.80 \pm 0.08$ & $0.87 \pm 0.06$ & 34 & 34 \\
\hline 0.86 & $43.0 \pm 3.5$ & $43.3 \pm 3.6$ & $0.98 \pm 0.04$ & $0.99 \pm 0.07$ & $4.9 \pm 2.4$ & $5.2 \pm 2.3$ & $0.110 \pm 0.051$ & $0.117 \pm 0.047$ & $0.24 \pm 0.07$ & $0.24 \pm 0.07$ & $11.84 \pm 2.52$ & $10.79 \pm 2.08$ & $9.89 \pm 1.77$ & $0.84 \pm 0.06$ & $0.92 \pm 0.04$ & 34 & 34 \\
\hline All & & & & & & & $0.078 \pm 0.036$ & $0.093 \pm 0.045$ & $0.35 \pm 0.05$ & $0.32 \pm 0.05$ & $11.90 \pm 2.79$ & $10.84 \pm 2.31$ & & & & 169 & 169 \\
\hline \multicolumn{18}{|c|}{ Fresh city pollution } \\
\hline 0.07 & $205.5 \pm 12.1$ & $241.8 \pm 33.0$ & $0.66 \pm 0.16$ & $0.69 \pm 0.10$ & $19.8 \pm 7.6$ & $59.7 \pm 26.8$ & $0.097 \pm 0.039$ & $0.239 \pm 0.079$ & $0.36 \pm 0.06$ & $0.24 \pm 0.09$ & $21.65 \pm 6.57$ & $12.43 \pm 3.83$ & $0.36 \pm 0.23$ & $0.02 \pm 0.01$ & $0.04 \pm 0.03$ & 25 & 25 \\
\hline 0.26 & $94.8 \pm 8.9$ & $105.5 \pm 15.1$ & $0.81 \pm 0.16$ & $0.84 \pm 0.12$ & $14.6 \pm 9.8$ & $24.6 \pm 15.3$ & $0.149 \pm 0.094$ & $0.219 \pm 0.121$ & $0.25 \pm 0.07$ & $0.19 \pm 0.09$ & $22.31 \pm 7.09$ & $11.78 \pm 3.62$ & $2.85 \pm 1.86$ & $0.15 \pm 0.12$ & $0.21 \pm 0.10$ & 38 & 38 \\
\hline 0.46 & $73.8 \pm 10.3$ & $76.4 \pm 11.4$ & $0.94 \pm 0.10$ & $0.96 \pm 0.05$ & $11.2 \pm 7.4$ & $13.1 \pm 8.1$ & $0.143 \pm 0.086$ & $0.162 \pm 0.090$ & $0.18 \pm 0.08$ & $0.17 \pm 0.08$ & $23.29 \pm 8.85$ & $11.63 \pm 3.82$ & $4.98 \pm 3.37$ & $0.25 \pm 0.21$ & $0.37 \pm 0.17$ & 39 & 39 \\
\hline 0.66 & $60.1 \pm 9.2$ & $61.7 \pm 10.4$ & $0.96 \pm 0.09$ & $0.96 \pm 0.03$ & $9.4 \pm 6.5$ & $10.9 \pm 7.4$ & $0.148 \pm 0.082$ & $0.165 \pm 0.093$ & $0.16 \pm 0.07$ & $0.16 \pm 0.07$ & $22.62 \pm 7.04$ & $11.75 \pm 3.86$ & $6.83 \pm 4.12$ & $0.34 \pm 0.24$ & $0.49 \pm 0.19$ & 39 & 39 \\
\hline 0.86 & $50.5 \pm 7.8$ & $51.5 \pm 8.8$ & $0.98 \pm 0.08$ & $0.99 \pm 0.04$ & $6.3 \pm 3.9$ & $7.0 \pm 4.6$ & $0.119 \pm 0.061$ & $0.127 \pm 0.069$ & $0.16 \pm 0.07$ & $0.16 \pm 0.07$ & $22.36 \pm 6.95$ & $11.90 \pm 3.72$ & $8.34 \pm 4.44$ & $0.42 \pm 0.26$ & $0.61 \pm 0.19$ & 40 & 40 \\
\hline All & & & & & & & $0.132 \pm 0.072$ & $0.182 \pm 0.090$ & $0.22 \pm 0.07$ & $0.18 \pm 0.08$ & $22.53 \pm 7.34$ & $11.90 \pm 3.73$ & & & & 181 & 181 \\
\hline \multicolumn{18}{|c|}{ PRIDE-PRD2006 entire campaign excluding BBE (from Rose et al., 2010) } \\
\hline 0.068 & $187.4 \pm 9.4$ & $211.8 \pm 21.5$ & $0.73 \pm 0.13$ & $0.73 \pm 0.14$ & $17.3 \pm 10.1$ & $56.9 \pm 26.7$ & $0.092 \pm 0.05$ & $0.261 \pm 0.11$ & $0.46 \pm 0.07$ & $0.33 \pm 010$ & & & $0.84 \pm 0.51$ & $0.05 \pm 0.03$ & & 378 & 282 \\
\hline 0.27 & $79.8 \pm 7.2$ & $83.1 \pm 9.5$ & $0.89 \pm 0.09$ & $0.93 \pm 0.10$ & $7.7 \pm 5.6$ & $12.5 \pm 9.5$ & $0.094 \pm 0.06$ & $0.143 \pm 0.10$ & $0.39 \pm 0.09$ & $0.35 \pm 0.11$ & & & $6.44 \pm 4.01$ & $0.34 \pm 0.16$ & & 378 & 282 \\
\hline 0.47 & $58.3 \pm 5.8$ & $59.1 \pm 6.6$ & $0.95 \pm 0.07$ & $0.98 \pm 0.08$ & $4.9 \pm 4.0$ & $5.7 \pm 4.9$ & $0.081 \pm$ & $0.092 \pm 0.06$ & $0.33 \pm 0.08$ & $0.32 \pm 0.09$ & & & $9.76 \pm 5.32$ & $0.52 \pm 0.19$ & & 385 & 291 \\
\hline 0.67 & $48.0 \pm 5.0$ & $48.6 \pm 5.0$ & $0.96 \pm 0.07$ & $0.99 \pm 0.08$ & $4.6 \pm 3.8$ & $5.4 \pm 4.2$ & $0.091 \pm 0.07$ & $0.106 \pm 0.08$ & $0.29 \pm 0.08$ & $0.28 \pm 0.08$ & & & $11.00 \pm 5.98$ & $0.60 \pm 0.21$ & & 275 & 208 \\
\hline 0.87 & $40.2 \pm 3.7$ & $40.2 \pm 3.7$ & $0.98 \pm 0.06$ & $1.01 \pm 0.08$ & $3.9 \pm 2.5$ & $4.2 \pm 2.8$ & $0.093 \pm 0.06$ & $0.100 \pm 0.06$ & $0.29 \pm 0.08$ & $0.29 \pm 0.08$ & & & $13.19 \pm 6.46$ & $0.70 \pm 0.19$ & & 374 & 282 \\
\hline All & & & & & & & $0.090 \pm 0.06$ & $0.140 \pm 0.08$ & $0.350 \pm 0.08$ & $0.310 \pm 0.09$ & 11 & & & & & 1891 & 1420 \\
\hline
\end{tabular}

Table 3. Best-fit parameters of monomodal lognormal size distribution functions fitted to the mean number size distribution of aerosol particles $(\mathrm{CN})$ for the entire campaign, the focus periods (aged regional pollution, fresh city pollution), and the mean number size distribution observed during PRIDE-PRD2006 (Rose et al., 2010): integral number concentration $\left(N_{\mathrm{CN}}\right)$, count median or geometric mean diameter $\left(D_{\mathrm{g}}\right)$, and geometric standard deviation $\left(\sigma_{\mathrm{g}}\right)$.

\begin{tabular}{lccl}
\hline Period & $N_{\mathrm{CN}}\left(\mathrm{cm}^{-3}\right)$ & $D_{\mathrm{g}}(\mathrm{nm})$ & $\sigma_{\mathrm{g}}$ \\
\hline Entire campaign & 15600 & 75 & 2.8 \\
Aged regional pollution & 11250 & 125 & 2 \\
Fresh city pollution & 22600 & 45 & 2.1 \\
PRIDE-PRD2006 (entire & 15125 & 66 & 1.90 \\
campaign excl. BBE) & & & \\
\hline
\end{tabular}

\section{Results and discussion}

\subsection{Campaign averages}

Figure 2 shows campaign averages of the CCN efficiency spectra (Fig. 2a), the effective hygroscopicity of CCN-active particles (Fig. 2b), the $\mathrm{CN}$ and $\mathrm{CCN}$ number size distributions (Fig. 2c), and the mass size distributions as obtained by the AMS (Fig. 2d). The average parameters derived from the $\mathrm{CCN}$ efficiency spectra are summarized in Table 2 (arithmetic mean \pm standard deviation), and the corresponding median values are given in the Supplement (Table S1).

The midpoint activation diameters, $D_{\mathrm{a}}$, increased with decreasing $S$ as expected from Köhler theory (Fig. 2a). At medium to high supersaturation levels $(S=0.26 \%$ to $0.86 \%)$, the $\mathrm{CCN}$ efficiency spectra generally reached up to one (maximum activated fraction $\mathrm{MAF}_{\mathrm{f}} \approx 1$ ) and the normalized standard deviations were small $\left(\sigma_{\mathrm{a}} / D_{\mathrm{a}} \approx 10 \%\right)$, which implies that nearly all aerosol particles larger than the midpoint activation diameter $\left(D>D_{\mathrm{a}}\right)$ were $\mathrm{CCN}$-active. At the lowest supersaturation level $(S=0.07 \%)$, however, the maximum activated fraction remained on average below one, which indicates the existence of externally mixed weakly $\mathrm{CCN}$-active particles with much lower hygroscopicity. The average value of $\mathrm{MAF}_{\mathrm{f}}$ was $\sim 0.8$ and the minimum values were as low as $\sim 0.4$, implying that on average $\sim 20 \%$ and up to $\sim 60 \%$ of the aerosol particles with diameters around $\sim 250 \mathrm{~nm}$ were not CCN-active at $S=0.07 \%$. According to the $\kappa$-Köhler model, particles larger than $\sim 250 \mathrm{~nm}$ that are not activated at $S=0.07 \%$ must have effective hygroscopicity parameters $\kappa<0.1$. Most of these particles, however, can activate at $S=0.26 \%$, corresponding to a minimum value of $\kappa=0.01$. Similarly high proportions of externally mixed weakly $\mathrm{CCN}$-active particles in polluted megacity air have been reported by Rose et al. (2010, 2011) for Guangzhou in the Pearl River Delta (PRIDE-PRD2006). Most likely these are externally mixed soot particles freshly emitted from 

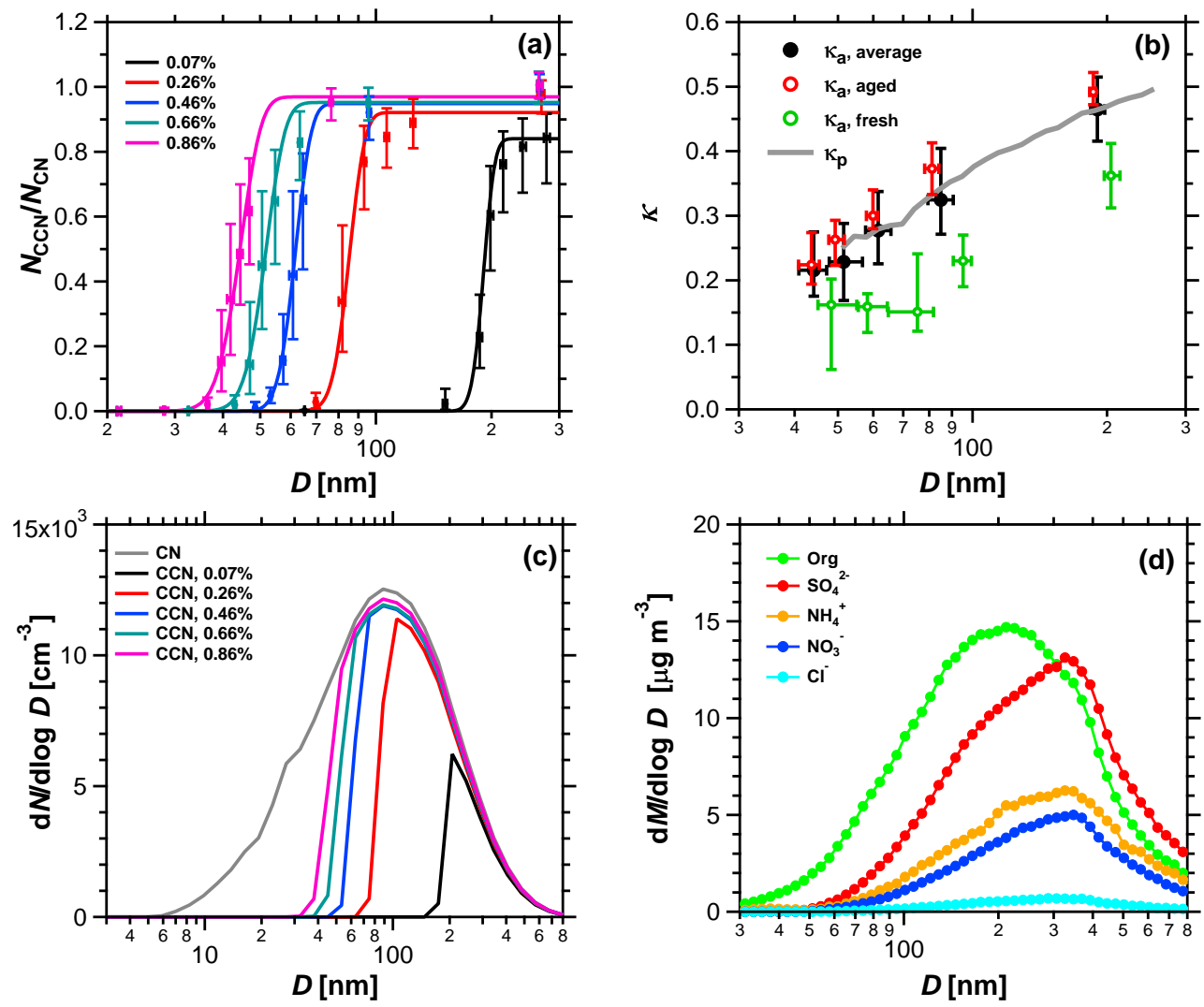

Fig. 2. Campaign-average CCN efficiency spectra (a), hygroscopicity parameters (b), number size distributions (c) and mass size distributions (d). Data points and lines represent median values; error bars represent lower and upper quartiles. (a) Size-resolved CCN efficiency spectra at different supersaturation levels $(S=0.07-0.86 \%)$ : activated particle fraction $N_{\mathrm{CCN}} / N_{\mathrm{CN}}$ plotted against mobility equivalent diameter $D$. The lines are 3-parameter cumulative Gaussian distribution function (CDF) fits. (b) Effective hygroscopicity of CCN-active particles $\left(\kappa_{\mathrm{a}}\right)$ plotted against the midpoint activation diameter $\left(D_{\mathrm{a}}\right)$. The black line represents the modeled/predicted hygroscopicity parameter $\left(\kappa_{\mathrm{p}}\right)$ as calculated from organic and inorganic mass fractions derived from AMS measurements averaged over the CCN measurement period and using rounded off values as obtained by extrapolating a linear fit in Fig. 5. (c) Number size distributions of total aerosol particles $(\mathrm{CN})$ and of cloud condensation nuclei $(\mathrm{CCN})$ averaged over the entire campaign (CCN measurement period where TDMPS data were available). The $\mathrm{CCN}$ size distributions were calculated by multiplying the median $\mathrm{CN}$ size distribution with the median $\mathrm{CCN}$ efficiency spectra. (d) Mass size distributions of organic matter and inorganic ions as determined by AMS and averaged over all AMS data available during the CCN measurement period (Fig. 3).

strong local and regional sources, which is consistent with the relatively high EC concentrations and EC/OC ratios observed in this study $\left(\sim 6 \mu \mathrm{g} \mathrm{m}^{-3} \mathrm{EC}, \mathrm{EC} / \mathrm{OC} \approx 1\right.$, Table 4$)$ and with the findings of related recent studies (Garland et al., 2008, 2009; Achtert et al., 2009; Cheng et al., 2009; Wehner et al., 2009; Su et al., 2010; Rose et al., 2010, 2011). Dust particles, which would have a similarly low hygroscopicity, are not likely to represent a significant fraction in the size range we investigated in our study $(<300 \mathrm{~nm})$, except for dust storm episodes (e.g. Wu et al., 2009). Remote sensing data, however, do not show any evidence for dust storm episodes during our measurement campaign (Fig. S1). The abundance, properties, and effects of the externally mixed, weakly $\mathrm{CCN}$-active particles shall be specifically addressed in follow-up studies.
Figure $2 b$ shows that the campaign average effective hygroscopicity of $\mathrm{CCN}$-active particles increased strongly with particle size. In the Aitken size range $(\sim 40-70 \mathrm{~nm}), \kappa_{\mathrm{a}}$ was on average between 0.2 and 0.3 , which is consistent with inorganic mass fractions $<50 \%$. In the accumulation size range $(\sim 70-200 \mathrm{~nm}), \kappa_{\mathrm{a}}$ increased up to $\sim 0.5$, which is due to enhanced mass fractions of sulfate and other soluble inorganic ions as illustrated in Fig. $2 \mathrm{~d}$ and discussed in Sect. 3.3. The observed increase of CCN hygroscopicity with increasing particle diameter is also consistent with the size dependence of aerosol hygroscopic growth factors reported by Achtert et al. (2009). Averaged over the entire range of aerosol particle sizes and water vapor supersaturations measured during the CAREBeijing-2006 campaign, the arithmetic mean value and standard deviation of the effective 
Table 4. Mass concentrations and corresponding mass fractions of organic matter and inorganic ions determined by aerosol mass spectrometry (AMS). Apparent elemental and organic carbon (EC, OC) mass concentrations determined by thermo-optical measurements and mass fractions of EC and OC relative to the estimated total concentration of fine particulate matter $\left(\mathrm{PM}_{1} \approx \Sigma\right.$ AMS $\left.+\mathrm{EC}\right)$. Arithmetic mean values and standard deviations are listed for the entire campaign and for the focus periods of aged regional pollution and of fresh city pollution.

\begin{tabular}{|c|c|c|c|c|c|c|}
\hline \multirow[b]{2}{*}{ Compound } & \multicolumn{3}{|c|}{ Mass concentration $\left(\mu \mathrm{g} \mathrm{m}^{-3}\right)$} & \multicolumn{3}{|c|}{ Mass fraction } \\
\hline & $\begin{array}{c}\text { Entire } \\
\text { campaign }\end{array}$ & $\begin{array}{l}\text { Aged regional } \\
\text { pollution }\end{array}$ & $\begin{array}{c}\text { Fresh city } \\
\text { pollution }\end{array}$ & $\begin{array}{c}\text { Entire } \\
\text { campaign }\end{array}$ & $\begin{array}{l}\text { Aged regional } \\
\text { pollution }\end{array}$ & $\begin{array}{l}\text { Fresh city } \\
\text { pollution }\end{array}$ \\
\hline Organics & $10.83 \pm 7.79$ & $15.4 \pm 4.00$ & $5.59 \pm 4.12$ & 0.410 & 0.317 & 0.731 \\
\hline $\mathrm{SO}_{4}^{2-}$ & $8.20 \pm 7.46$ & $18.13 \pm 4.92$ & $1.02 \pm 2.71$ & 0.311 & 0.374 & 0.133 \\
\hline $\mathrm{NH}_{4}^{+}$ & $4.07 \pm 3.23$ & $8.29 \pm 3.26$ & $0.52 \pm 2.91$ & 0.154 & 0.171 & 0.068 \\
\hline $\mathrm{NO}_{3}^{-}$ & $2.88 \pm 2.51$ & $5.74 \pm 3.19$ & $0.45 \pm 1.89$ & 0.109 & 0.118 & 0.059 \\
\hline $\mathrm{Cl}^{-}$ & $0.41 \pm 0.61$ & $0.98 \pm 0.91$ & $0.07 \pm 1.17$ & 0.016 & 0.020 & 0.009 \\
\hline$\sum \mathrm{AMS}$ & $26.4 \pm 19.8$ & $48.5 \pm 20.1$ & $7.6 \pm 8.2$ & 1.000 & 1.000 & 1.000 \\
\hline $\mathrm{EC}$ & $6.0 \pm 3.1$ & $4.8 \pm 1.4$ & $3.1 \pm 2.1$ & 0.18 & 0.09 & 0.34 \\
\hline $\mathrm{OC}$ & $6.4 \pm 4.0$ & $7.0 \pm 2.7$ & $3.9 \pm 3.6$ & 0.20 & 0.13 & 0.36 \\
\hline$\sum \mathrm{AMS}+\mathrm{EC}$ & 32.4 & 53.3 & 10.7 & 1.00 & 1.00 & 1.00 \\
\hline
\end{tabular}

hygroscopicity parameters for the $\mathrm{CCN}$-active particles $\left(\kappa_{\mathrm{a}}\right)$ as well as for the total ensemble of aerosol particles $\left(\kappa_{\mathrm{t}}\right.$, Sect. 2.2.2) were $\kappa_{\mathrm{a}} \approx \kappa_{\mathrm{t}} \approx 0.3 \pm 0.1$ (Table 2). This is consistent with other measurements, estimates and model calculations for the effective average hygroscopicity of aerosols in populated regions (Andreae and Rosenfeld, 2008; Bougiatioti et al., 2009; Pöschl et al., 2009; Shinozuka et al., 2009; Chang et al., 2010; Kammermann et al., 2010; Pringle et al., 2010; Rose et al., 2010, 2011; Jurányi et al., 2011, and references therein).

As illustrated in Fig. 2c, the campaign average number size distribution of total aerosol particles $(\mathrm{CN})$ peaked near $\sim 100 \mathrm{~nm}$, and the mean and median values of $N_{\mathrm{CN} \text {,tot }}$ were $1.6 \times 10^{4} \mathrm{~cm}^{-3}$ (Table 2) and $1.0 \times 10^{4} \mathrm{~cm}^{-3}$ (Table S1), respectively. At $S=0.07 \%$ the average $\mathrm{CCN}$ activation diameter was much larger than the modal diameter of the $\mathrm{CN}$ size distribution $(\sim 200 \mathrm{~nm})$, and the $\mathrm{CCN}$ size distributions accounted only for $\sim 10 \%$ of $N_{\mathrm{CN} \text {, tot }}(\sim 20 \%$ of $N_{\mathrm{CN}, 30}$, Table 2). At the higher supersaturation levels, the $\mathrm{CCN}$ activation diameters were smaller, and the integral CCN efficiencies reached up to $\sim 70 \%$ of $N_{\mathrm{CN} \text {,tot }}$ ( $\sim 80 \%$ of $N_{\mathrm{CN}, 30}$, Table 2 ). Compared to the global mean value of $N_{\mathrm{CCN}, \mathrm{S}} / N_{\mathrm{CN} \text {,tot }} \approx 0.36$ at $S \approx 0.4 \%$ suggested by Andreae (2009), the campaign average value was higher $\left(N_{\mathrm{CCN}, \mathrm{S}} / N_{\mathrm{CN}, \text { tot }} \approx 0.5\right)$ but the average value for the fresh city pollution period discussed below was lower $\left(N_{\mathrm{CCN}, \mathrm{S}} / N_{\mathrm{CN}, \text { tot }} \approx 0.2\right)$.

The best fit parameters for a monomodal lognormal distribution fitted to the average $\mathrm{CN}$ size distribution are listed in Table 3 (mean) and in Table S2 (median), respectively. The campaign average number concentrations of $\mathrm{CCN}$ were in the range of $N_{\mathrm{CCN}, \mathrm{S}} \approx 2 \times 10^{3} \mathrm{~cm}^{-3}$ at $S=0.07 \%$ to $N_{\mathrm{CCN}, \mathrm{S}} \approx 1 \times 10^{4} \mathrm{~cm}^{-3}$ at $S=0.86 \%$ (Table 2). This is consistent with the values recently reported by Deng et al. (2011) for Wuqing, a town located between Beijing and Tianjin in the Northern China plain.
The campaign average mass size distributions measured by AMS (Fig. 2d) peaked at mass equivalent diameters around $\sim 200 \mathrm{~nm}$ for organic matter and around $\sim 350 \mathrm{~nm}$ for sulfate, nitrate and ammonium ions. As discussed by Takegawa et al. (2009a), the peak diameter of the sulfate mass size distribution exhibited an increase with aging time due to strong secondary sulfate formation. On average, the total mass concentration determined by AMS and integrated over the investigated size range $(29-900 \mathrm{~nm})$ was $\sim 26 \mu \mathrm{g} \mathrm{m}^{-3}$ with an organic mass fraction of $\sim 40 \%$ and a sulfate mass fraction of $\sim 30 \%$ sulfate. The mass fractions of other inorganic ions are listed in Table 4.

\subsection{Time series and focus periods}

Figure 3 shows the temporal evolution and variability of several parameters characteristic for the meteorological conditions, CCN properties, and aerosol composition observed throughout the measurement campaign. For clarity, the CCN parameters are plotted only for the lowest and the highest supersaturation level investigated. The temporal evolution of these parameters determined at intermediate supersaturation levels was generally similar to the one at $S=0.86 \%$.

Most parameters exhibited more or less pronounced diurnal cycles and some episodes with drastically different characteristics. For example, the integral CCN efficien$\operatorname{cies}\left(N_{\mathrm{CCN}} / N_{\mathrm{CN}, \text { tot }}, N_{\mathrm{CCN}} / N_{\mathrm{CN}, 30}\right)$, the maximum activated fraction at low supersaturation $\left(\mathrm{MAF}_{\mathrm{f}}\right.$ at $\left.S=0.07 \%\right)$, and the inorganic mass fraction determined by AMS exhibited a strong decrease on 20 August and on 3 September. Similar temporal patterns and episodes were reported by Garland et al. (2009), Achtert et al. (2009), and Takegawa et al. (2009a), who found that major changes in aerosol optical properties and chemical composition during CAREBeijing2006 could be attributed to changes in the prevailing meteorological conditions, e.g. wind speed, wind direction, and air mass origin (back trajectories). To explore the relationship 


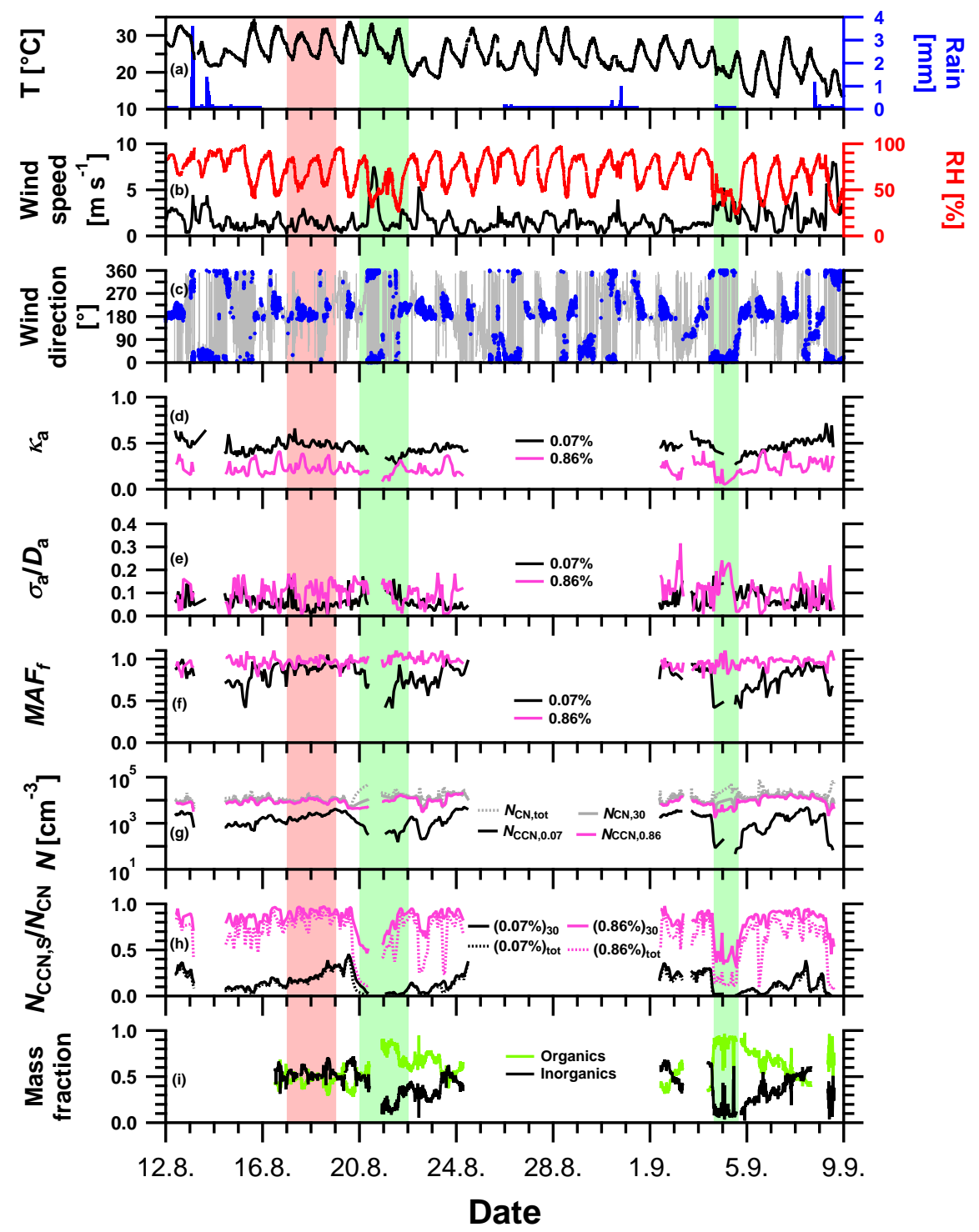

Fig. 3. Time series of meteorological parameters, CCN properties, and aerosol composition: (a) ambient temperature (black), and rain fall (blue), (b) wind speed (black) and ambient relative humidity (red), (c) wind direction for all observed wind speeds (grey shade) and for wind speed $>2 \mathrm{~m} \mathrm{~s}^{-1}$ (blue); (d) effective hygroscopicity of CCN-active particles, (e, f) heterogeneity (normalized width) and maximum activated fraction (amplitude) of 3-parameter CDF fit to observed CCN efficiency spectra, (g) number concentrations of total aerosol particles $\left(N_{\mathrm{CN}, \text { tot }}\right)$, particles with $D>30 \mathrm{~nm}\left(N_{\mathrm{CN}, 30}\right)$, and of cloud condensation nuclei, (h) integral CCN efficiencies relative to $N_{\mathrm{CN} \text {,tot }}$ and to $N_{\mathrm{CN}, 30}$; (i) organic and inorganic mass fractions determined by AMS and integrated over the investigated size range (29-900 nm). All the parameters are plotted against the date in August-September 2006 (local time). The CCN parameters are plotted for the lowest and the highest investigated supersaturation level $(S=0.07 \%$ and $0.86 \%)$. The red and green shaded areas indicate the aged regional and fresh city pollution episodes, respectively.

between air mass origin and CCN properties, we highlight two distinct focus periods:

1. A focus period of "aged regional pollution", when stagnant air masses came from the highly industrialized regions south of Beijing, where numerous power plants and factories are located, and passed over the measurement site with relatively low wind speed (17 August 00:00 to 18 August 23:59 LT; shaded red in Fig. 3).
2. A focus period of "fresh city pollution", when clean air masses came from the mountain regions in the north, passed over the city center of Beijing with relatively high wind speed (frontal passage), and arrived at the measurement site from wind directions ranging from northeast to northwest (20 August 00:00 to $21 \mathrm{Au}$ gust 23:59LT, and 3 September 15:00 to 4 September 15:00 LT; shaded green in Fig. 3). 

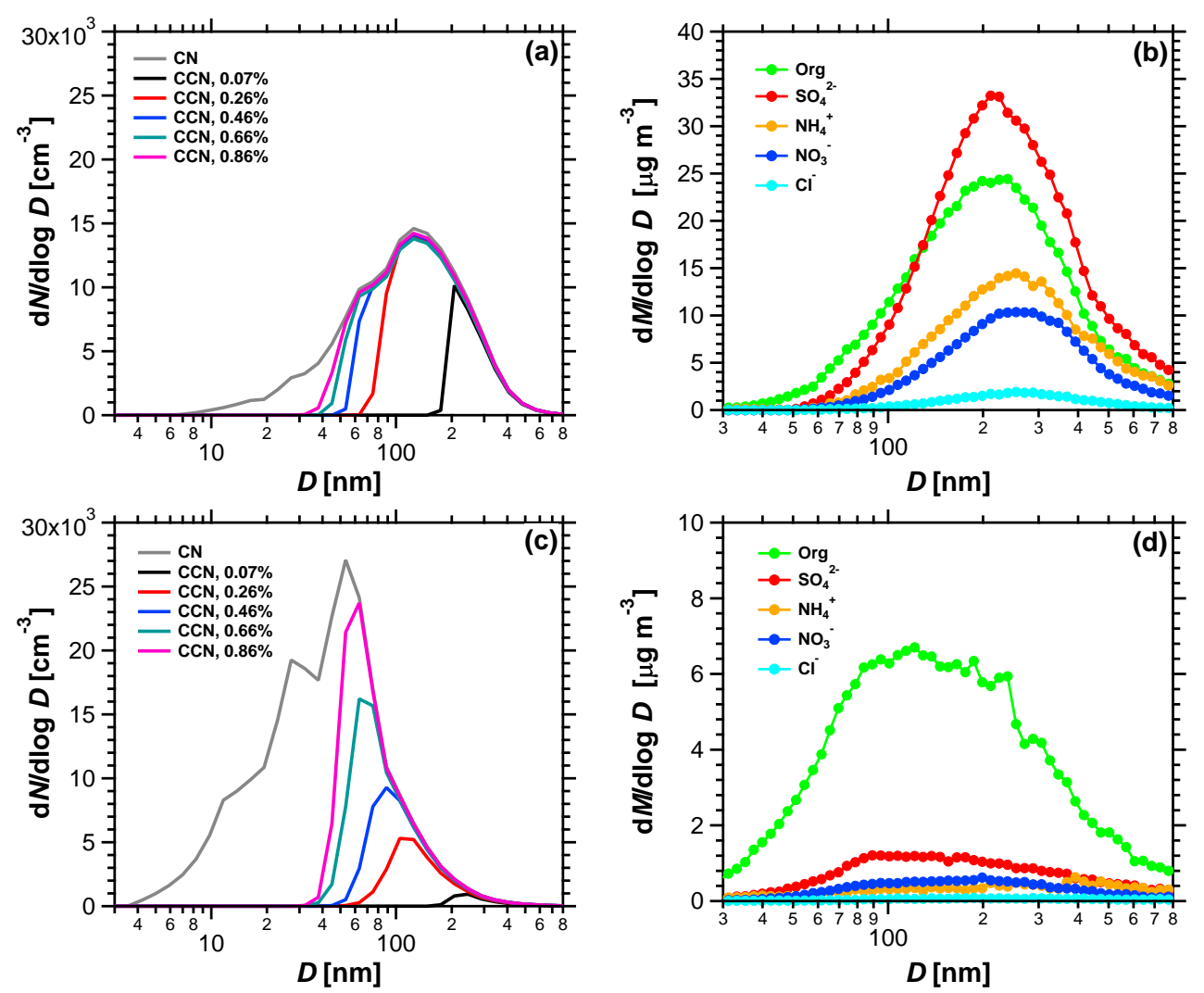

Fig. 4. Number size distributions of total aerosol particles $(\mathrm{CN})$ and of cloud condensation nuclei (CCN) for different supersaturation levels (left column; panels a, c), and mass size distributions of organic and inorganic compounds determined by AMS (right column; panels b, d). The upper panels $(\mathbf{a}, \mathbf{b})$ are averages over the aged regional pollution period and the lower panels (c, d) are averages over the fresh city pollution period.

The dates of these focus periods were selected according to the back trajectory analysis and the air mass classification in Table 2 of Garland et al. (2009), taking into account the availability of the CCN and AMS data. For both periods, Fig. 4 shows the average number size distributions of $\mathrm{CN}$ and $\mathrm{CCN}$ as well as the mass size distributions of organic matter and inorganic ions determined by AMS. Characteristic parameters of aerosol composition and $\mathrm{CCN}$ activity are summarized in Tables 2, 3, and 4 (mean values), and in the supplementary Tables S1, S2, and S3 (median values).

During the focus period for aged regional pollution (shaded red in Fig. 3), the meteorological parameters as well as some of the aerosol and $\mathrm{CCN}$ properties were qualitatively similar to the campaign average conditions outlined above (Sect. 3.1, Fig. 2). Differences could be observed in the total aerosol particle number size distribution that peaked at a larger diameter $(\sim 120 \mathrm{~nm}$, Fig. $4 \mathrm{a})$, and in the mass concentrations determined by AMS that were enhanced by factors of 1.5-2 (Fig. 4b, Table 4) compared to the campaign average. The concentrations of sulfate and other inorganic ions were also more strongly enhanced than that of organic compounds, which led to an increase in the hygroscopicity of CCN active particles $\left(\kappa_{\mathrm{a}}=0.35 \pm 0.05\right)$. Moreover, the maximum activated fractions of $\mathrm{CCN}$ measured at low supersaturation were enhanced $\left(\mathrm{MAF}_{\mathrm{f}}=0.91\right.$ at $\left.S=0.07 \%\right)$, which indicates a relatively low abundance of externally mixed weakly $\mathrm{CCN}$-active particles. Due to the increased particle size, increased hygroscopicity, and decreased fraction of externally mixed weakly $\mathrm{CCN}$-active particles, the integral $\mathrm{CCN}$ efficiencies were also higher than the campaign average values: from $\sim 20 \%$ of $N_{\mathrm{CN} \text {, tot }}\left(\sim 20 \%\right.$ of $\left.N_{\mathrm{CN}, 30}\right)$ at $S=0.07 \%$ up to $\sim 80 \%$ of $N_{\mathrm{CN} \text {,tot }}\left(\sim 90 \%\right.$ of $\left.N_{\mathrm{CN}, 30}\right)$ at $S=0.86 \%$ (Table 2).

During the focus period for fresh city pollution (shaded green in Fig. 3), the aerosol and CCN properties differed drastically from the focus period for aged regional pollution. The total aerosol particle number size distribution peaked at a much lower diameter in the Aitken size range ( $\sim 50 \mathrm{~nm}$, Fig. $4 \mathrm{c}$ ), and the mass concentrations determined by AMS were reduced by factors of 2 to 8 (Fig. $4 \mathrm{~d}$, Table 4). The concentrations of sulfate and other inorganic ions were more strongly reduced than that of organic compounds, which led to a decrease in the hygroscopicity of $\mathrm{CCN}$ active particles $\left(\kappa_{\mathrm{a}}=0.22 \pm 0.07\right)$. Moreover, the maximum 
activated fractions of $\mathrm{CCN}$ measured at low supersaturation were reduced $\left(\mathrm{MAF}_{\mathrm{f}}=0.66\right.$ at $\left.S=0.07 \%\right)$, which indicates a relatively high abundance of externally mixed weakly $\mathrm{CCN}$-active particles. Due to the strongly decreased particle size, decreased hygroscopicity, and increased fraction of externally-mixed weakly $\mathrm{CCN}$-active particles, the integral $\mathrm{CCN}$ efficiencies were substantially lower than during the aged regional pollution period: from $\sim 2 \%$ of $N_{\mathrm{CN}}$, tot $(\sim 4 \%$ of $\left.N_{\mathrm{CN}, 30}\right)$ at $S=0.07 \%$ up to $\sim 40 \%$ of $N_{\mathrm{CN} \text {,tot }}(\sim 60 \%$ of $N_{\mathrm{CN}, 30}$ ) at $S=0.86 \%$ (Table 2). Thus, the number concentrations of $\mathrm{CCN}$ were lower by as much as a factor of $\sim 7$ at $S=0.07 \%$ to a factor of $\sim 1.2$ at $S=0.86 \%$ although the total aerosol particle number concentrations were higher by a factor of $\sim 2$.

\subsection{Relationship between aerosol chemical composition and hygroscopicity}

As outlined above and in earlier studies, the effective hygroscopicity of CCN-active particles can be efficiently linked to the organic and inorganic mass fractions determined by AMS measurements (Gunthe et al., 2009; Dusek et al., 2010; Rose et al., 2011).

Figure 5 shows the correlation of $\kappa_{\mathrm{a}}$ with the organic mass fraction determined by integration over the relevant diameter range in the AMS mass size distribution ( $D_{\mathrm{a}} \pm \sigma_{\mathrm{a}}$, Sect. 2.2.3) using the data points for which the mass concentration in the integration interval was larger than $1 \mu \mathrm{g} \mathrm{m}^{-3}\left(R^{2}=0.78\right)$. Using all available data points, we obtained a weaker correlation $\left(R^{2}=0.37\right)$, which can be explained by the limited reliability of mass fractions calculated from AMS data with low concentration in the relevant size range $\left(m_{\mathrm{D}}<1 \mu \mathrm{g} \mathrm{m}^{-3}\right.$, Rose et al., 2011).

Extrapolation of the fit line in Fig. 5 to $f_{\text {org }}=1$ yields an estimate of $\kappa_{\text {org }}=0.06 \pm 0.01$ for the effective average hygroscopicity of the non-refractory organic particulate matter in the investigated aerosols. This is consistent with the average value of $\kappa_{\text {org }} \approx 0.1$ derived from earlier field and laboratory studies (Gunthe et al., 2009; Jimenez et al., 2009; Shinozuka et al., 2009; King et al., 2009; Dusek et al., 2010; Roberts et al., 2010; Rose et al., 2011). Extrapolation of the fit line to $f_{\text {org }}=0$ yields an estimate of $\kappa_{\text {inorg }}=0.68 \pm 0.02$ for the effective average hygroscopicity of the non-refractory inorganic particulate matter. This is similar to the characteristic values for ammonium sulfate and related compounds (Petters and Kreidenweis, 2007) and consistent with the average values of $\kappa_{\text {inorg }} \approx 0.6-0.7$ derived from earlier field studies (Gunthe et al., 2009; Dusek et al., 2010; Rose et al., 2011).

Based on the observed correlation, and in analogy to earlier studies, we can use the following simple mixing rule to predict effective hygroscopicity parameters from AMS measurement data (Gunthe et al., 2009; Dusek et al., 2010; Rose et al., 2011):

$\kappa_{\mathrm{p}}=\kappa_{\text {org }} \cdot f_{\text {org }}+\kappa_{\text {inorg }} \cdot f_{\text {inorg }}$

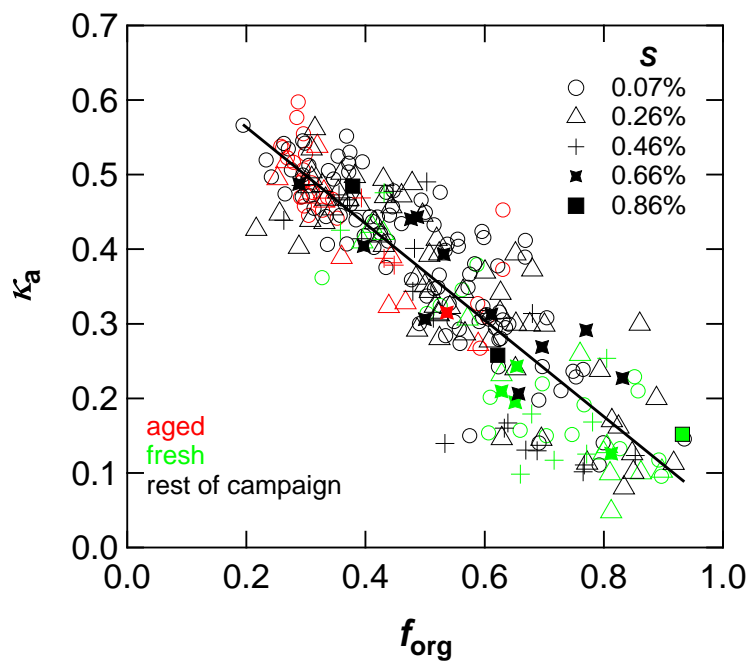

Fig. 5. Correlation between the effective hygroscopicity parameter of $\mathrm{CCN}$-active particles $\left(\kappa_{\mathrm{a}}\right)$ and the size-integrated organic mass fraction $\left(f_{\text {org }}\right)$ as determined by AMS measurements for the aged regional pollution period (red), the fresh city pollution period (green), and the rest of the campaign (black). Different symbols indicate different supersaturation levels. The black line is a linear least square fit with the following equation, correlation coefficient, and number of data points: $y=0.684-0.623 x, R^{2}=0.78, n=271$.

As illustrated in Fig. 6, the size dependence of the particle hygroscopicity as predicted from the AMS measurement data with rounded average values of $\kappa_{\text {org }}=0.1$ and $\kappa_{\text {inorg }}=0.7$ generally agrees well with the effective average hygroscopicity parameters derived from the $\mathrm{CCN}$ measurements. An apparent overprediction of $\kappa_{\mathrm{a}}$ in the Aitken size range during the focus period of fresh city pollution $(<100 \mathrm{~nm}$, Fig. 6c) is likely due to enhanced mass fractions of internally mixed soot and elemental carbon (Table 4), which are not captured by the AMS data. In addition, the chemical composition and effective hygroscopicity parameter of the organic and inorganic fractions may be different during the fresh city pollution. Possibilities for improvement using additional data from complementary measurement techniques (e.g. from volatility or hygroscopicity tandem differential mobility analyzers; Rose et al., 2011; Su et al., 2010) and the impact on the prediction of $\mathrm{CCN}$ and cloud droplet number concentrations will be explored in follow-up studies.

\subsection{Comparison between the megacity regions of Beijing and Guangzhou}

Directly before the CAREBeijing-2006 campaign, the same instrumentation and experimental setup had been used in the PRIDE-PRD2006 campaign to measure the CCN properties and chemical composition of the aerosol particles at a rural site (Backgarden) $\sim 60 \mathrm{~km}$ northwest of the emerging megacity Guangzhou in the Pearl River Delta (PRD) (Rose et al., 2010, 2011). During the PRIDE-PRD2006 campaign, 

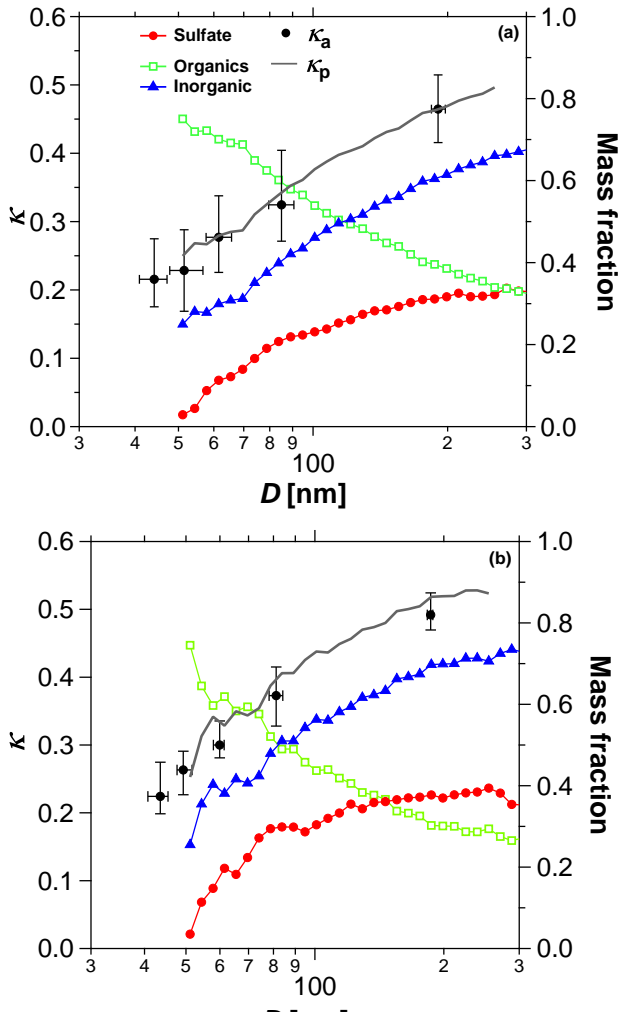

$D[\mathrm{~nm}]$

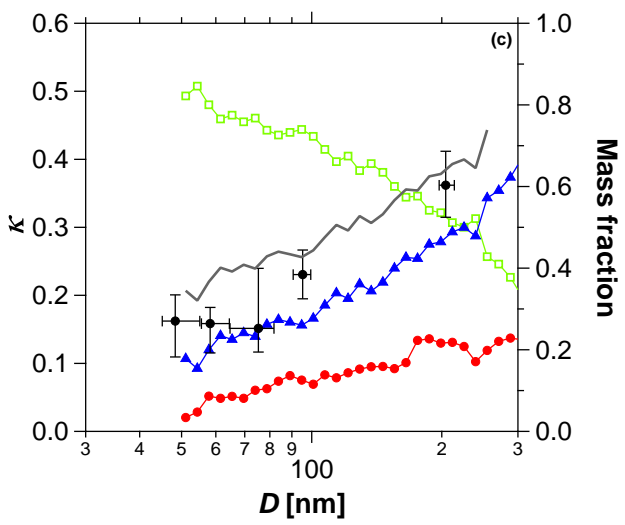

Fig. 6. Size distributions of mass fractions of organic (green), inorganic (blue), and sulfate (red) as determined by the AMS (cut-off at $50 \mathrm{~nm}$ ), and the observed effective hygroscopicity parameter of $\mathrm{CCN}$-active particles ( $\kappa_{\mathrm{a}}$, black data points, median values with error bars extending to upper and lower quartiles) averaged over the entire campaign (a), the aged regional pollution period (b), and the fresh city pollution period (c). The grey line in each panel indicates the effective hygroscopicity parameter $\left(\kappa_{\mathrm{p}}\right)$ modeled/predicted from the corresponding median organic and inorganic mass fractions as determined by size-resolved AMS measurements calculated by using rounded off values as obtained by extrapolating a linear fit in Fig. $5\left(\kappa_{\mathrm{p}}=f_{\text {org }} \cdot 0.1+f_{\text {inorg }} \cdot 0.7\right)$. Data points at which $m_{\mathrm{D}}<1 \mu \mathrm{g} \mathrm{m}^{-3}$ were excluded. the air masses generally originated from the southeast, and passed over the highly industrialized PRD region, which includes Hong Kong, Guangzhou and several other cities, before arriving at the Backgarden measurement site (monsoon circulation prevailed during the campaign).

During PRIDE-PRD2006 the meteorological conditions were less variable than during CAREBeijing-2006, and the sampled air masses contained a mix of city pollution from Guangzhou, and regional pollution from the Pearl River Delta (Garland et al., 2008; Rose et al., 2010, 2011). For the comparison with Beijing, we used the PRIDE-PRD2006 data set "entire campaign excluding the biomass burning event" from Rose et al. (2010, 2011). In this data set, the highly polluted period of 23-26 July 2006, which was characterized by intense local biomass burning, was excluded. A similar comparison between data from CAREBeijing-2006 and PRIDEPRD2006 has been done for the aerosol optical properties by Garland et al. (2009).

The parameter values characterizing the composition and CCN activity of aerosols observed during PRIDE-PRD2006 fell mostly between the values observed in the different focus periods of CAREBeijing-2006, but were closer to the focus period of aged regional pollution (Tables 2 and 3). Compared to this focus period, the aerosols sampled during PRIDE-PRD2006 exhibited similar hygroscopicity parameters for $\mathrm{CCN}$-active particles $\left(\kappa_{\mathrm{a}} \approx 0.35\right)$ but higher proportions of externally mixed weakly $\mathrm{CCN}$-active particles ( $\sim 27 \%$ vs. $\sim 9 \%$ at $S \approx 0.07 \%$ ), smaller peak diameters of the $\mathrm{CN}$ size distribution $(\sim 70 \mathrm{~nm}$ vs. $\sim 90 \mathrm{~nm})$, and lower integral CCN efficiencies ( $\sim 5 \%$ vs. $\sim 22 \%$ at $S \approx 0.07 \%$ and $\sim 70 \%$ vs. $\sim 84 \%$ at $S \approx 0.86 \%$ ). Thus, the $\mathrm{CCN}$ concentrations at low supersaturation were lower $\left(\sim 0.8 \times 10^{3} \mathrm{~cm}^{-3}\right.$ vs. $\sim 2.5 \times 10^{3} \mathrm{~cm}^{-3}$ at $S \approx 0.07 \%$ ), although the total $\mathrm{CN}$ number concentrations were higher $\left(\sim 1.8 \times 10^{4} \mathrm{~cm}^{-3}\right.$ vs. $\sim 1.2 \times 10^{4} \mathrm{~cm}^{-3}$ ).

Compared to the focus period of fresh city pollution in CAREBeijing-2006, the aerosols sampled during PRIDEPRD2006 exhibited substantially higher hygroscopicity parameters for $\mathrm{CCN}$-active particles $(\sim 0.35$ vs. $\sim 0.22)$, lower proportions of externally mixed weakly $\mathrm{CCN}$-active particles $(\sim 27 \%$ vs. $\sim 34 \%$ at $S \approx 0.07 \%)$, larger peak diameters of the $\mathrm{CN}$ size distribution $(\sim 70 \mathrm{~nm}$ vs. $\sim 50 \mathrm{~nm})$, and higher integral $\mathrm{CCN}$ efficiencies $(\sim 5 \%$ vs. $\sim 2 \%$ at $S \approx 0.07 \%$ and $\sim 70 \%$ vs. $\sim 42 \%$ at $S \approx 0.86 \%$ ). Thus, the $\mathrm{CCN}$ concentrations were generally higher $(\sim(0.8-$ 13) $\times 10^{3} \mathrm{~cm}^{-3}$ vs. $\left.\sim(0.4-8) \times 10^{3} \mathrm{~cm}^{-3}\right)$, although the total $\mathrm{CN}$ number concentrations were lower $\left(\sim 1.8 \times 10^{4} \mathrm{~cm}^{-3}\right.$ vs. $\sim 2.2 \times 10^{4} \mathrm{~cm}^{-3}$ ).

Overall, both the meteorological conditions and the CCN properties of PRIDE-PRD2006 represent a mix of aged regional pollution from the Pearl River Delta and fresh city pollution from Guangzhou, whereas the meteorological conditions and CCN properties of CAREBeijing-2006 exhibited a clear separation between aged regional pollution in 
stagnant air masses, and fresh city pollution in the outflow from Beijing during frontal passages.

\section{Summary and conclusions}

During the CAREBeijing-2006 campaign, we performed the first size-resolved CCN measurements in the megacity region of Beijing. The $\mathrm{CCN}$ hygroscopicity exhibited a strong size dependence, ranging from $\kappa_{\mathrm{a}}=0.25$ to 0.45 , i.e. particles in the Aitken size range were much less hygroscopic than in the accumulation size range. Averaged over the entire range of measured aerosol particle size and water vapor supersaturation, the mean value and standard deviation of the $\mathrm{CCN}$ hygroscopicity were $\kappa_{\mathrm{a}} \approx 0.3 \pm 0.1$ This is consistent with other measurements, estimates and model calculations for the effective average hygroscopicity of aerosols in populated continental regions (Andreae and Rosenfeld, 2008; Bougiatioti et al., 2009; Pöschl et al., 2009; Shinozuka et al., 2009; Chang et al., 2010; Kammermann et al., 2010; Pringle et al., 2010; Rose et al., 2010, 2011; Jurányi et al., 2011, and references therein).

The CCN hygroscopicity and its size dependence could be parameterized as a function of AMS-based organic and inorganic mass fractions using the simple mixing rule $\kappa_{\mathrm{p}} \approx$ $0.1 \cdot f_{\text {org }}+0.7 \cdot f_{\text {inorg }}$. An apparent overprediction of $\kappa_{\mathrm{a}}$ in the Aitken size range during the focus period of fresh city pollution was likely due to enhanced mass fractions of internally mixed soot and elemental carbon, which are not captured by the AMS. Possibilities for improvement by additional data from complementary measurement techniques (e.g. from volatility or hygroscopicity tandem differential mobility analyzers; Rose et al., 2011; Su et al., 2010) and the impact on the prediction of CCN and cloud droplet number concentrations will be explored in follow-up studies.

When the measured air masses originated from the north and passed rapidly over the center of Beijing (fresh city pollution), the average particle hygroscopicity was reduced $(\kappa=0.2 \pm 0.1)$, which is consistent with enhanced mass fractions of organic compounds $\left(\sim 50 \%\right.$ of $\left.\mathrm{PM}_{1}\right)$ and elemental carbon ( $\sim 30 \%$ of $\left.\mathrm{PM}_{1}\right)$. Moreover, substantial fractions of weakly $\mathrm{CCN}$-active particles with much lower hygroscopicity were observed at low supersaturation $(S=0.07 \%)$, which can be explained as being from freshly emitted, externally mixed soot particles. Particles in stagnant air from the industrialized megacity region south of Beijing (aged regional pollution) were on average larger and more hygroscopic, which is consistent with enhanced mass fractions ( $\sim 60 \%)$ of soluble inorganic ions (mostly sulfate, ammonium, and nitrate). Accordingly, the number concentration of $\mathrm{CCN}$ in aged air from the megacity region was higher $\left((2.5-9.9) \times 10^{3} \mathrm{~cm}^{-3}\right.$ vs. $(0.4-8.3) \times 10^{3} \mathrm{~cm}^{-3}$ for $\left.S=0.07-0.86 \%\right)$ although the total aerosol particle number concentration was lower than in the fresh city outflow $\left(1.2 \times 10^{4} \mathrm{~cm}^{-3}\right.$ vs. $\left.2.3 \times 10^{4} \mathrm{~cm}^{-3}\right)$.
Prior to CAREBeijing-2006, the same experimental equipment and scientific approach had been used in the PRIDEPRD2006 campaign to characterize the $\mathrm{CCN}$ properties and chemical composition of aerosol particles at a rural location in the megacity region of Guangzhou in the Pearl River Delta (Rose et al., 2010, 2011). Both the meteorological conditions and the CCN properties of PRIDE-PRD2006 were characteristic for a mix of aged regional pollution from the Pearl River Delta and fresh urban pollution from Guangzhou. The systematic analysis and comparison of the data sets from CAREBeijing-2006 and PRIDE-PRD2006 suggest that the fresh outflow from Chinese megacity centers generally contains more, but smaller and less hygroscopic aerosol particles, and thus fewer $\mathrm{CCN}$ than the aged outflow from megacity regions.

\section{Supplementary material related to this article is available online at: http://www.atmos-chem-phys.net/11/11023/2011/ acp-11-11023-2011-supplement.pdf.}

Acknowledgements. Corresponding authorship is shared by S. S. Gunthe (s.gunthe@iitm.ac.in) and D. Rose (d.rose@mpic.de). The CAREBeijing-2006 (Campaign of Air Quality Research in Beijing and surrounding areas in 2006) was supported by the Beijing Council of Science and Technology (HB200504-6, HB200504-2). This study was supported by the Max Planck Society (MPG), the Leibniz Institute for Tropospheric Research (IfT), the University of Tokyo (UT), and Peking University (PKU). The authors gratefully acknowledge SEDAC (Socioeconomic Data and Application Center) for the population density data used in this publication. Thanks are owed to all the team members of CAREBeijing-2006 for support during the campaign and fruitful discussions afterwards.

The service charges for this open access publication have been covered by the Max Planck Society.

Edited by: M. Gauss

\section{References}

Achtert, P., Birmili, W., Nowak, A., Wehner, B., Wiedensohler, A., Takegawa, N., Kondo, Y., Miyazaki, Y., Hu, M., and Zhu, T.: Hygroscopic growth of tropospheric particle number size distributions over the North China Plain, J. Geophys. Res., 114, D00G07, doi:10.1029/2008JD010921, 2009.

Andreae, M. O.: Correlation between cloud condensation nuclei concentration and aerosol optical thickness in remote and polluted regions, Atmos. Chem. Phys., 9, 543-556, doi:10.5194/acp-9-543-2009, 2009.

Andreae, M. O. and Gelencsér, A.: Black carbon or brown carbon? The nature of light-absorbing carbonaceous aerosols, Atmos. Chem. Phys., 6, 3131-3148, doi:10.5194/acp-6-3131-2006, 2006. 
Andreae, M. O. and Rosenfeld, D.: Aerosol-cloud-precipitation interactions. Part 1. The nature and sources of cloud-active aerosols, Earth Sci. Rev., 89, 13-41, 2008.

Andreae, M. O., Jones, C. D., and Cox, P. M.: Strong present-day aerosol cooling implies a hot future, Nature, 435, 1187-1190, 2005.

Birmili, W., Stratmann, F., and Wiedensohler, A.: Design of a DMA-based size spectrometer for a large particle size range and stable operation, J. Aerosol Sci., 30, 549-553, 1999.

Bougiatioti, A., Fountoukis, C., Kalivitis, N., Pandis, S. N., Nenes, A., and Mihalopoulos, N.: Cloud condensation nuclei measurements in the marine boundary layer of the Eastern Mediterranean: CCN closure and droplet growth kinetics, Atmos. Chem. Phys., 9, 7053-7066, doi:10.5194/acp-9-7053-2009, 2009.

Chang, R. Y.-W., Slowik, J. G., Shantz, N. C., Vlasenko, A., Liggio, J., Sjostedt, S. J., Leaitch, W. R., and Abbatt, J. P. D.: The hygroscopicity parameter $(\kappa)$ of ambient organic aerosol at a field site subject to biogenic and anthropogenic influences: relationship to degree of aerosol oxidation, Atmos. Chem. Phys., 10, 50475064, doi:10.5194/acp-10-5047-2010, 2010.

Chen, D. S., Cheng, S. Y., Liu, L., Chen, T., and Guo, X. R.: An integrated MM5-CMAQ modeling approach for assessing transboundary $\mathrm{PM}_{10}$ contribution to the host city of 2008 Olympic summer games - Beijing, China, Atmos. Environ., 41, 12371250, doi:10.1016/j.atmosenv.2006.09.045, 2007.

Cheng, Y. F., Berghof, M., Garland, R. M., Wiedensohler, A., Wehner, B., Müller, T., Su, H., Zhang, Y. H., Achtert, P., Nowak, A., Pöschl, U., Zhu, T., Hu, M., and Zeng, L. M.: Influence of soot mixing state on aerosol light absorption and single scattering albedo during air mass aging at a polluted regional site in northeastern China, J. Geophys. Res., 114, D00G10, doi:10.1029/2008JD010883, 2009.

DeCarlo, P. F., Slowik, J. G., Worsnop, D. R., Davidovits, P., and Jimenez, J. L.: Particle Morphology and Density Characterization by Combined Mobility and Aerodynamic Diameter Measurements. Part 1: Theory, Aerosol Sci. Technol., 38, 11851205, 2004.

Deng, Z. Z., Zhao, C. S., Ma, N., Liu, P. F., Ran, L., Xu, W. Y., Chen, J., Liang, Z., Liang, S., Huang, M. Y., Ma, X. C., Zhang, Q., Quan, J. N., Yan, P., Henning, S., Mildenberger, K., Sommerhage, E., Schäfer, M., Stratmann, F., and Wiedensohler, A.: Size-resolved and bulk activation properties of aerosols in the North China Plain, Atmos. Chem. Phys., 11, 3835-3846, doi:10.5194/acp-11-3835-2011, 2011.

Dusek, U., Frank, G. P., Curtius, J., Drewnick, F., Schneider, J., Kürten, A., Rose, D., Andreae, M. O., Borrmann, S., and Pöschl, U.: Enhanced organic mass fraction and decreased hygroscopicity of cloud condensation nuclei $(\mathrm{CCN})$ during new particle formation events, Geophys. Res. Lett., 37, L03804, doi:10.1029/2009GL040930, 2010.

Frank, G. P., Dusek, U., and Andreae, M. O.: Technical note: A method for measuring size-resolved $\mathrm{CCN}$ in the atmosphere, Atmos. Chem. Phys. Discuss., 6, 4879-4895, doi:10.5194/acpd-64879-2006, 2006.

Garland, R. M., Yang, H., Schmid, O., Rose, D., Nowak, A., Achtert, P., Wiedensohler, A., Takegawa, N., Kita, K., Miyazaki, Y., Kondo, Y., Hu, M., Shao, M., Zeng, L. M., Zhang, Y. H., Andreae, M. O., and Pöschl, U.: Aerosol optical properties in a rural environment near the mega-city Guangzhou, China: im- plications for regional air pollution, radiative forcing and remote sensing, Atmos. Chem. Phys., 8, 5161-5186, doi:10.5194/acp-85161-2008, 2008.

Garland, R. M., Schmid, O., Nowak, A., Achtert, P., Wiedensohler, A., Gunthe, S. S., Takegawa, N., Kita, K., Kondo, Y., Hu, M., Shao, M., Zeng, L. M., Zhu, T., Andreae, M. O., and Pöschl, U.: Aerosol optical properties observed during Campaign of Air Quality Research in Beijing 2006 (CAREBeijing2006): Characteristic differences between the inflow and outflow of Beijing city air, J. Geophys. Res., 114, D00G04, doi:10.1029/2008JD010780, 2009.

Gunthe, S. S., King, S. M., Rose, D., Chen, Q., Roldin, P., Farmer, D. K., Jimenez, J. L., Artaxo, P., Andreae, M. O., Martin, S. T., and Pöschl, U.: Cloud condensation nuclei in pristine tropical rainforest air of Amazonia: size-resolved measurements and modeling of atmospheric aerosol composition and CCN activity, Atmos. Chem. Phys., 9, 7551-7575, doi:10.5194/acp-9-75512009, 2009.

Huang, Y., Chameides, W. L., and Dickinson, R. E.: Direct and indirect effects of anthropogenic aerosols on regional precipitation over east Asia, J. Geophys. Res., 112, D03212, doi:10.1029/2006JD007114, 2007.

IPCC: Climate Change 2007: The Physical Science Basis. Contribution of Working Group I to the Fourth Assessment Report of the Intergovernmental Panel on Climate Change, p. 996, Cambridge University Press, Cambridge and New York, 2007.

Jayne, J. T., Leard, D. C., Zhang, X. F., Davidovits, P., Smith, K. A., Kolb, C. E., and Worsnop, D. R.: Development of an aerosol mass spectrometer for size and composition analysis of submicron particles, Aerosol Sci. Technol., 33, 49-70, 2000.

Jimenez, J. L., Canagaratna, M. R., Donahue, N. M., Prevot, A. S. H., Zhang, Q., Kroll, J. H., DeCarlo, P. F., Allan, J. D., Coe, H., Ng, N. L., Aiken, A. C., Docherty, K. S., Ulbrich, I. M., Grieshop, A. P., Robinson, A. L., Duplissy, J., Smith, J. D., Wilson, K. R., Lanz, V. A., Hueglin, C., Sun, Y. L., Tian, J., Laaksonen, A., Raatikainen, T., Rautiainen, J., Vaattovaara, P., Ehn, M., Kulmala, M., Tomlinson, J. M., Collins, D. R., Cubison, M. J., Dunlea, E. J., Huffman, J. A., Onasch, T. B., Alfarra, M. R., Williams, P. I., Bower, K., Kondo, Y., Schneider, J., Drewnick, F., Borrmann, S., Weimer, S., Demerjian, K., Salcedo, D., Cottrell, L., Griffin, R., Takami, A., Miyoshi, T., Hatakeyama, S., Shimono, A., Sun, J. Y., Zhang, Y. M., Dzepina, K., Kimmel, J. R., Sueper, D., Jayne, J. T., Herndon, S. C., Trimborn, A. M., Williams, L. R., Wood, E. C., Middlebrook, A. M., Kolb, C. E., Baltensperger, U., and Worsnop, D. R.: Evolution of Organic Aerosols in the Atmosphere, Science, 326, 1525-1529, doi:10.1126/science.1180353, 2009.

Jurányi, Z., Gysel, M., Weingartner, E., Bukowiecki, N., Kammermann, L., and Baltensperger, U.: A 17 month climatology of the cloud condensation nuclei number concentration at the high alpine site Jungfraujoch, J. Geophys. Res., 116, D10204, doi:10.1029/2010JD015199, 2011.

Kammermann, L., Gysel, M., Weingartner, E., and Baltensperger, U.: 13-month climatology of the aerosol hygroscopicity at the free tropospheric site Jungfraujoch (3580 m a.s.1.), Atmos. Chem. Phys., 10, 10717-10732, doi:10.5194/acp-10-107172010, 2010.

King, S. M., Rosenoern, T., Shilling, J. E., Chen, Q., and Martin, S. T.: Increased cloud activation potential of secondary organic 
aerosol for atmospheric mass loadings, Atmos. Chem. Phys., 9, 2959-2971, doi:10.5194/acp-9-2959-2009, 2009.

Kondo, Y., Komazaki, Y., Miyazaki, Y., Moteki, N., Takegawa, N., Kodama, D., Deguchi, S., Nogami, M., Fukuda, M., and Miyakawa, T.: Temporal variations of elemental carbon in Tokyo, J. Geophys. Res, 111, D12205, doi:10.1029/2005JD006257, 2006.

Kreidenweis, S. M., Petters, M. D., and Chuang, P. Y.: Cloud particle precursors, in: Clouds in the Perturbed Climate System: Their Relationship to Energy Balance, Atmospheric Dynamics, and Precipitation, Strüngmann Forum Report, vol. 2, edited by: Heintzenberg, J. and Charlson, R. J., MIT Press, Cambridge, MA, 2009.

Kuwata, M., Kondo, Y., Mochida, M., Takegawa, N., and Kawamura, K.: Dependence of CCN activity of less volatile particles on the amount of coating observed in Tokyo, J. Geophys. Res., 112, D11207, doi:10.1029/2006JD007758, 2007.

Kuwata, M., Kondo, Y., Miyazaki, Y., Komazaki, Y., Kim, J. H., Yum, S. S., Tanimoto, H., and Matsueda, H.: Cloud condensation nuclei activity at Jeju Island, Korea in spring 2005, Atmos. Chem. Phys., 8, 2933-2948, doi:10.5194/acp-8-2933-2008, 2008.

Kuwata, M., Kondo, Y., and Takegawa, N.: Critical condensed mass for activation of black carbon as cloud condensation nuclei in Tokyo, J. Geophys. Res., 114, D20202, doi:10.1029/2009JD012086, 2009.

Lance, S., Medina, J., Smith, J. N., and Nenes, A.: Mapping the Operation of the DMT Continuous Flow CCN Counter, Aerosol Sci. Technol., 40, 242-254, 2006.

Lathem, T. L. and Nenes, A.: Water Vapor Depletion in the DMT Continuous-Flow CCN Chamber: Effects on Supersaturation and Droplet Growth, Aerosol Sci. Technol., 45, 604-615, doi:10.1080/02786826.2010.551146, 2011.

Li, Z. Q., Xia, X., Cribb, M., Mi, W., Holben, B., Wang, P., Chen, H., Tsay, S. C., Eck, T. F., Zhao, F., Dutton, E. G., and Dickerson, R. E.: Aerosol optical properties and their radiative effects in northern China, J. Geophys. Res., 112, D22S01, doi:10.1029/2006JD007382, 2007.

Liu, B. H., Xu, M., Henderson, M., Qi, Y., and Li, Y. Q.: Taking China's temperature: Daily range, warming trends, and regional variations, 1955-2000, J. Climate, 17, 4453-4462, 2004.

Lohmann, U. and Feichter, J.: Global indirect aerosol effects: a review, Atmos. Chem. Phys., 5, 715-737, doi:10.5194/acp-5-7152005, 2005.

Massie, S. T., Torres, O., and Smith, S. J.: Total Ozone Mapping Spectrometer (TOMS) observations of increases in Asian aerosol in winter from 1979 to 2000, J. Geophys. Res., 109, D18211, doi:10.1029/2004JD004620, 2004.

Matsui, H., Koike, M., Kondo, Y., Takegawa, N., Fast, J. D., Pöschl, U., Garland, R. M., Andreae, M. O., Wiedensohler, A., Sugimoto, N., and Zhu, T.: Spatial and temporal variations of aerosols around Beijing in summer 2006: 2. Local and column aerosol optical properties, J. Geophys. Res., 115, D22207, doi:10.1029/2010JD013895, 2010.

Matsumoto, K., Tanaka, H., Nagao, I., and Ishizaka, Y.: Contribution of particulate sulfate and organic carbon to cloud condensation nuclei in the marine atmosphere, Geophys. Res. Lett., 24, 655-658, 1997.

Mikhailov, E., Vlasenko, S., Martin, S. T., Koop, T., and Pöschl,
U.: Amorphous and crystalline aerosol particles interacting with water vapor: conceptual framework and experimental evidence for restructuring, phase transitions and kinetic limitations, Atmos. Chem. Phys., 9, 9491-9522, doi:10.5194/acp-9-9491-2009, 2009.

Petters, M. D. and Kreidenweis, S. M.: A single parameter representation of hygroscopic growth and cloud condensation nucleus activity, Atmos. Chem. Phys., 7, 1961-1971, doi:10.5194/acp-71961-2007, 2007.

Pöschl, U., Rose, D., and Andreae, M. O.: Climatologies of cloudrelated aerosols - Part 2: Particle hygroscopicity and cloud condensation nucleus activity, in: Clouds in the Perturbed Climate System: Their Relationship to Energy Balance, Atmospheric Dynamics, and Precipitation, Strüngmann Forum Report, vol. 2, edited by: Heintzenberg, J. and Charlson, R. J., MIT Press, Cambridge, MA, 57-72, 2009.

Pöschl, U., Martin, S. T., Sinha, B., Chen, Q., Gunthe, S. S., Huffman, J. A., Borrmann, S., Farmer, D. K., Garland, R. M., Helas, G., Jimenez, J. L., King, S. M., Manzi, A., Mikhailov, E., Pauliquevis, T., Petters, M. D., Prenni, A. J., Roldin, P., Rose, D., Schneider, J., Su, H., Zorn, S. R., Artaxo, P., and Andreae, M. O.: Rainforest aerosols as biogenic nuclei of clouds and precipitation in the Amazon, Science, 329, 1513-1516, 2010.

Pringle, K. J., Tost, H., Pozzer, A., Pöschl, U., and Lelieveld, J.: Global distribution of the effective aerosol hygroscopicity parameter for $\mathrm{CCN}$ activation, Atmos. Chem. Phys., 10, 52415255, doi:10.5194/acp-10-5241-2010, 2010.

Qian, Y., Kaiser, D. P., Leung, L. R., and Xu, M.: More frequent cloud-free sky and less surface solar radiation in China from 1955 to 2000, Geophys. Res. Lett., 33, L01812, doi:10.1029/2005GL024586, 2006.

Richter, A., Burrows, J. P., Nüss, H., Granier, C., and Niemeier, U.: Increase in tropospheric nitrogen dioxide over China observed from space, Nature, 437, 129-132, doi:10.1038/nature04092, 2005.

Roberts, G. C. and Nenes, A.: A Continuous-Flow Streamwise Thermal-Gradient CCN Chamber for Atmospheric Measurements, Aerosol Sci. Technol., 39, 206-221, 2005.

Roberts, G. C., Day, D. A., Russell, L. M., Dunlea, E. J., Jimenez, J. L., Tomlinson, J. M., Collins, D. R., Shinozuka, Y., and Clarke, A. D.: Characterization of particle cloud droplet activity and composition in the free troposphere and the boundary layer during INTEX-B, Atmos. Chem. Phys., 10, 6627-6644, doi:10.5194/acp-10-6627-2010, 2010.

Rose, D., Gunthe, S. S., Mikhailov, E., Frank, G. P., Dusek, U., Andreae, M. O., and Pöschl, U.: Calibration and measurement uncertainties of a continuous-flow cloud condensation nuclei counter (DMT-CCNC): $\mathrm{CCN}$ activation of ammonium sulfate and sodium chloride aerosol particles in theory and experiment, Atmos. Chem. Phys., 8, 1153-1179, doi:10.5194/acp-8-11532008, 2008.

Rose, D., Nowak, A., Achtert, P., Wiedensohler, A., Hu, M., Shao, M., Zhang, Y., Andreae, M. O., and Pöschl, U.: Cloud condensation nuclei in polluted air and biomass burning smoke near the mega-city Guangzhou, China - Part 1: Size-resolved measurements and implications for the modeling of aerosol particle hygroscopicity and CCN activity, Atmos. Chem. Phys., 10, 3365 3383, doi:10.5194/acp-10-3365-2010, 2010.

Rose, D., Gunthe, S. S., Su, H., Garland, R. M., Yang, H., 
Berghof, M., Cheng, Y. F., Wehner, B., Achtert, P., Nowak, A., Wiedensohler, A., Takegawa, N., Kondo, Y., Hu, M., Zhang, Y., Andreae, M. O., and Pöschl, U.: Cloud condensation nuclei in polluted air and biomass burning smoke near the megacity Guangzhou, China - Part 2: Size-resolved aerosol chemical composition, diurnal cycles, and externally mixed weakly CCN-active soot particles, Atmos. Chem. Phys., 11, 2817-2836, doi:10.5194/acp-11-2817-2011, 2011.

Rosenfeld, D., Dai, J., Yu, X., Yao, Z., Xu, X., Yang, X., and Du, C.: Inverse relations between amounts of air pollution and orographic precipitation, Science, 315, 1396-1398, 2007.

Rosenfeld, D., Lohmann, U., Raga, G. B., O'Dowd, C. D., Kulmala, M., Fuzzi, S., Reissell, A., and Andreae, M. O.: Flood or Drought: How Do Aerosols Affect Precipitation?, Science, 321, 5894, 2008.

Seinfeld, J. H. and Pandis, S. N.: Atmospheric Chemistry and Physics: From Air Pollution to Climate Change, John Wiley and Sons, Inc., New York, 2006.

Shao, M., Tang, X., Zhang, Y., and Li, W.: City clusters in China: air and surface water pollution, Front. Ecol. Environ., 4, 353361, 2006.

Shinozuka, Y., Clarke, A. D., DeCarlo, P. F., Jimenez, J. L., Dunlea, E. J., Roberts, G. C., Tomlinson, J. M., Collins, D. R., Howell, S. G., Kapustin, V. N., McNaughton, C. S., and Zhou, J.: Aerosol optical properties relevant to regional remote sensing of $\mathrm{CCN}$ activity and links to their organic mass fraction: airborne observations over Central Mexico and the US West Coast during MILAGRO/INTEX-B, Atmos. Chem. Phys., 9, 6727-6742, doi:10.5194/acp-9-6727-2009, 2009.

Stevens, B. and Feingold, G.: Untangling aerosol effects on clouds and precipitation in a buffered system, Nature, 461, 7264, doi:10.1038/nature08281, 2009.

Streets, D. G., Tsai, N. Y., Akimoto, H., and Oka, K.: Sulfur dioxide emissions in Asia in the period 1985-1997, Atmos. Environ., 34, 4413-4424, 2000.

Streets, D. G., Fu, J. S., Jang, C. J., Hao, J. M., He, K. B., Tang, X. Y., Zhang, Y. H., Wang, Z. F., Li, Z. P., Zhang, Q., Wang, L. T., Wang, B. Y., and Yu, C.: Air quality during the 2008 Beijing Olympic Games, Atmos. Environ., 41, 480-492, 2007.

Streets, D. G., Yu, C., Wu, Y., Chin, M., Zhao, Z., Hayasaka, T., and Shi, G.: Aerosol trends over China, 1980-2000, Atmos. Res., 88, 174-182, 2008.

Su, H., Rose, D., Cheng, Y. F., Gunthe, S. S., Massling, A., Stock, M., Wiedensohler, A., Andreae, M. O., and Pöschl, U.: Hygroscopicity distribution concept for measurement data analysis and modeling of aerosol particle mixing state with regard to hygroscopic growth and CCN activation, Atmos. Chem. Phys., 10, 7489-7503, doi:10.5194/acp-10-7489-2010, 2010.

Takegawa, N., Miyakawa, T., Kuwata, M., Kondo, Y., Zhao, Y., Han, S., Kita, K., Miyazaki, Y., Deng, Z., Xiao, R., Hu, M., van Pinxteren, D., Herrmann, H., Hofzumahaus, A., Holland, F., Wahner, A., Blake, D. R., Sugimoto, N., , and Zhu, T.: Variability of submicron aerosol observed at a rural site in Beijing in the summer of 2006, J. Geophys. Res., 114, D00G05, doi:10.1029/2008JD010857, 2009a.

Takegawa, N., Miyakawa, T., Watanabe, M., Kondo, Y., Miyazaki, Y., Han, S., Zhao, Y., van Pinxteren, D., Brüggemann, E., Gnauk, T., Herrmann, H., Xiao, R., Deng, Z., Hu, M., Zhu, T., and Zhang, Y.: Performance of an Aerodyne Aerosol Mass
Spectrometer (AMS) during Intensive Campaigns in China in the Summer of 2006, Aerosol Sci. Technol., 43, 189-204, doi:10.1080/02786820802582251, 2009b.

Tuch, T. M., Haudek, A., Müller, T., Nowak, A., Wex, H., and Wiedensohler, A.: Design and performance of an automatic regenerating adsorption aerosol dryer for continuous operation at monitoring sites, Atmos. Meas. Tech., 2, 417-422, doi:10.5194/amt-2-417-2009, 2009.

van Pinxteren, D., Brüggemann, E., Gnauk, T., Iinuma, Y., Müller, K., Nowak, A., Achtert, P., Wiedensohler, A., and Herrmann, H.: Size- and time-resolved chemical particle characterization during CAREBeijing-2006: different pollution regimes and diurnal profiles, J. Geophys. Res., 114, D00G09, doi:10.1029/2008JD010890, 2009.

Wang, X., Carmichael, G., Chen, D., Tang, Y., and Wang, T.: Impacts of different emission sources on air quality during March 2001 in the Pearl River Delta (PRD) region, Atmos. Environ., 39, 5227-5241, 2005.

Wehner, B., Birmili, W., Ditas, F., Wu, Z., Hu, M., Liu, X., Mao, J., Sugimoto, N., and Wiedensohler, A.: Relationships between submicrometer particulate air pollution and air mass history in Beijing, China, 2004-2006, Atmos. Chem. Phys., 8, 6155-6168, doi:10.5194/acp-8-6155-2008, 2008.

Wehner, B., Berghof, M., Cheng, Y. F., Achtert, P., Birmili, W., Nowak, A., Wiedensohler, A., Garland, R. M., Pöschl, U., Hu, M., and Zhu, T.: Mixing state of nonvolatile aerosol particle fractions and comparison with light absorption in the polluted Beijing region, J. Geophys. Res., 114, D00G17, doi:10.1029/2008JD010923, 2009.

Wiedensohler, A., Cheng, Y. F., Nowak, A., Wehner, B., Achtert, P., Berghof, M., Birmili, W., Wu, Z. J., Hu, M., Zhu, T., Takegawa, N., Kita, K., Kondo, Y., Lou, S. R., Hofzumahaus, A., Holland, F., Wahner, A., Gunthe, S. S., Rose, D., Su, H., and Pöschl, U.: Rapid aerosol particle growth and increase of cloud condensation nucleus activity by secondary aerosol formation and condensation: A case study for regional air pollution in northeastern China, J. Geophys. Res., 114, D00G08, doi:10.1029/2008JD010884, 2009.

Wu, Z. J., Cheng, Y. F., Hu, M., Wehner, B., Sugimoto, N., and Wiedensohler, A.: Dust events in Beijing, China (20042006): comparison of ground-based measurements with columnar integrated observations, Atmos. Chem. Phys., 9, 6915-6932, doi:10.5194/acp-9-6915-2009, 2009.

Xia, X., Chen, H., and Zhang, W.: Analysis of the dependence of column-integrated aerosol properties on long-range transport of air masses in Beijing, Atmos. Environ., 41, 7739-7750, 2007.

$\mathrm{Xu}, \mathrm{Q}$.: Abrupt change of the mid-summer climate in central east China by the influence of atmospheric pollution, Atmos. Environ., 35, 5029-5040, 2001.

Yum, S. S., Hudson, J. G., Song, K. Y., and Choi, B.C.: Springtime cloud condensation nuclei concentrations on the west coast of Korea, Geophys. Res. Lett., 32, L09814, doi:10.1029/2005GL022641, 2005.

Yum, S. S., Roberts, G., Kim, J. H., Song, K. Y., and Kim, D. Y.: Submicron aerosol size distributions and cloud condensation nuclei concentrations measured at Gosan, Korea, during the Atmospheric brown clouds East Asian Regional Experiment 2005, J. Geophys. Res., 112, D22S32, doi:10.1029/2006JD008212, 2007. 
Zhang, Y. L., Qin, B. Q., and Chen, W. M.: Analysis of 40 year records of solar radiation data in Shanghai, Nanjing and Hangzhou in Eastern China, Theo. Appl. Climat., 78, 217-227, 2004.
Zhao, C., Tie, X., and Lin, Y.: A possible positive feedback of reduction of precipitation and increase in aerosols over eastern central China, Geophys. Res. Lett., 33, L11814, doi:10.1029/2006GL025959, 2006. 